\title{
DOKTORUN SORUMLULUĞUNDA ŞANS KAYBI : İYILEŞME ŞANSININ KAYBI
}

\author{
Dr. Yıldız ABIK*
}

\section{GíRiş}

Doktorların sorumluluğu davalarında, özellikle görevi ihmal davranışıyla zarar arasındaki illiyet bağını kanıtlamak zordur. Bu alan, hastanın daha önceki sağlık durumuyla, hastalığın daha sonraki ilerleme süreci bakımından, geniş ölçüde belirsizliklerin iz bıraktığı bir alandır. Her şeyden önce, tıp alanında her türlü illiyet bağının belirlenememesi sebebiyle, faydası olabilecek bütün deliller gözönünde tutulmalı ve somut olayın eksik bir değerlendirilmesinden kaçınılarak, sadece hastanın iyileşme olasılığg bakımından, hastalığın nasıl ilerleyeceğine ilişkin bir tahmin yapılmalıdır. $\mathrm{Bu}$ şekilde, çoğu zaman, illiyet bağının asla belirgin olmamasının sakıncaları ortadan kaldırılabilir ${ }^{1}$. Bu ispat zorlukları, ispat yükünün ters çevrilmesi veya illiyet bağının varlığının ispatlanmasına ilişkin taleplerin çürütülmesi suretiyle ispatın kolaylaştırılması ile giderilebilir. Bunun sonucu olarak, belirsiz illiyete rağmen meydana gelen tüm zarar tazmin edilir. Doktorun sorumluluğunda, sorumluluk hukukunun "ya hep ya hiç prensibinde (Allesoder- Nichts- Grundsatz)" yapılan bu tespit, gittikçe daha çok tartışılmaktadır. Fransa'daki mahkemeler ve A.B.D'deki bazı yargısal kararlar, iyileşme olasılığına göre ölçülen maddi tazminatın paylaştırılmasına izin vermektedir ve benzeri eğilimler, Avusturalya, İsviçre,

\footnotetext{
* Ankara Üniversitesi Hukuk Fakültesi Medeni Hukuk Anabilim Dalı Araştırma Görevlisi.

${ }^{1}$ Kasche, Maria : Verlust von Heilungschancen : eine rectsvergleichende Untersuchung, Frankfurt am Main, Berlin, Bern, Bruxelles, New York, Wien : Lang 1999, s. 1; Brennan, T.A. : "Causal Chains and Statistical Links : The Role of Scientific Uncertainty in Hazardous - Substance Litigation”, 73 Cornell Law Review (CornLRev) s. 469 - 533 , 469 - 490 (1988); Wachsmuth, W. / Schreiber, H.L. : "Sicherheit und Wahrscheinlichkeit - juristische und ärztlicheAspekte”, Neue Juristische Wochenschrift (NJW) 1982, s. 2094 - 2098.
} 
Avusturya'da da görülmektedir. Bilimsel bir belirlilik kanaatine varılan sorumluluk hukuku alanlarında ya hep ya hiç prensibinden uzaklaşılması ve bu sebepten dolayı bu prensibin yumuşatılması gerekliliği anlayışı ortak arka planda yer almaktadır. Doktorun sorumluluğunda özellikle iyileşme şansının kayb $^{2}$ (perte d'une chance / loss of chance) hukuki kurumu artan bir önem taşımaktadır. Doktor önerilen tedaviyi hiç yapmadıysa veya uygun olmayan şekilde yürüttüyse, hastanın iyileșme şansının önceki hastalığının başından itibaren belirsiz olması yüzünden ve bundan dolayı tam bir sorumluluk veya tam bir sorumsuzluğun yerinde olmadığ 1 kabul edilerek şartlar adil olarak değerlendirilmelidir. İyileşme şansının kaybettirilmesi halinde ya ispatın kolaylaştırılması ya da iyileşme olasılığının belirlenerek davacı hastanın kısmi (indirilmiş) tazminat hakkının bulunduğuna hükmedilmesi gerekir ${ }^{3}$. Şans kaybı hukuki kurumunun gelişmesi, ayırdedici özellikleri ve şartları ile uygulama alanı Almanya'da şimdiye kadar sadece az sayıda çalışmaya konu olmuştur ${ }^{4}$. Bu konuyla ilgili geniş kapsamlı ve karşılaştırmalı hukuk çalışması niteliğindeki bir inceleme İngilizce olarak da mevcut değildir 5 . Fransız ve A.B.D'nin federal devletlerindeki farklı hukuk düzenleri arasında bir karşılaştırma bu yeni hukuki kurumun çerçevesini belirginleştirmek ve ortaya çıkma nedenini açıklığa kavuşturmak bakımından iyi olacaktır. Önerilen bu doktorların sorumluluğundaki şans kaybı (perte d'une chance / loss of chance) hukuki kurumunun savunmas1, bu hukuk düzenlerindeki hukuki düşüncelere esas olan fikirlerin uygulanmasından bahsedilmesini de kolaylaştıracaktır. Şansla ilgili bu hukuki düşünceler, Alman hukukunda

\footnotetext{
2 İyileşme şansının kaybı, Almanca'da "verlorenen Heilungschance” şeklinde ifade edilebilir. Almanca'da şans kaybı için Fransız hukukunda kullanılan "perte d'une chance", İngiliz ve Amerikan hukukunda kullanılan "loss of chance" terimleri gibi belirgin bir terim yoktur.

${ }^{3}$ Kasche, s. 1-2.

${ }^{4}$ Burada her şeyden önce şu çalışmayı anmak gerekir: Stoll, H. : "Schadensersatz für verlorene Heilungschancen vor englischen Gerichten in rechtsvergleichender Sicht", Festschrift für E.Steffen (1995), s. 465- 478. Ayrica bkz. Deutsch, E. : Anmerkung zu BGH, 3.12.1985 VI ZR 106 / 84, NJW 1986, s. 1541; Franzki, D. : Die Beweisregeln im Arzthaftungsprozeß (1982); Giesen, D. : Anmerkung zu OLG Köln, 30.5.1990 27 U 169 / 89 JR 1991, s. 460; Giesen, D. : Arzthaftungsrecht (1995) Rn. 58; Kleinewefers, H. / Wilts, W. : "Die Beweislast für die Ursächlichkeit ärztlicher Kunstfehler", VersR 1967, s. 617-625; Matthies, K.H. : Schiedsinstanzen im Bereich der Arzthaftung : Soll und Haben (1984) s. 94 101. Müller - Stoy, Şans Kaybının Tazmini şeklinde Türkçeye çevrilebilecek tezinin başlığına rağmen, iyileşme şansının kaybıyla yeterince ilgilenmemiș ve bu konuyla ilgili yargısal kararlar üzerinde pek durmamıştır. (Müller - Stoy, Walter : Schadensersatz für verlorene Chancen, Dissertation, Freiburg im Breisgau 1973).

5 Stoll, Hans : "Schadensersatz für verlorene Heilungschancen vor englischen Gerichten in rechtsvergleichender Sicht" , Festschrift für E. Steffen (1995), s. 465-478; Stark, Emil W.: "Die Perte d'une chance im schweizerischen Recht", Colloque Développements récents du droit la responsabilité civile, hgg. Von Olivier Guillod, Zürich 1991, s. 101-109; Weir, Tony : "Loss of chance- Compensable in Tort?" The Common Law", Colloque Développements récents du droit la responsabilité civile, hgg. Von Olivier Guillod , Zürich 1991, s. 111-129; Chabas, François : "La perte d'une chance en droit français" Colloque Développements récents du droit la responsabilité civile, hgg. Von Olivier Guillod, Zürich 1991, s. 131-143.
} 
bağımsız bir önem kazanamamıștır. Bundan dolayı, bu hukuki kurumun doğrudan doğruya alınmasının Alman sorumluluk hukuku bakımından geçerliliği zor görünmektedir ${ }^{6}$.

Türk hukukunda, doktrinde şans kaybı ve bundan doğan zarar üzerinde durulmamıştır. Yargıtay'ın son yıllarda özellikle doktorların sorumluluğu ile ilgili verdiği bazı kararlarda $^{7}$ şans kaybı teorisinin etkisi olduğu kanaatindeyiz; ancak bu kararlardan açıkça bu teorinin kabul edildiği anlaşılamamaktadır.

Türk hukuku açısından da şans kaybı teorisinin tanıtılması, incelenmesi ve doktrinde yapılacak değerlendirmelerden sonra kabul edilip edilemeyeceğinin tartışmaya açılması uygun olacaktır.

\section{I.Genel Olarak}

Şanslar ve bunların kaybedilmesi, bazı hukuk düzenlerinde tazmin edilecek zararın dayandırılacağı esasın bulunması bakımından hukuki bir öneme sahiptir. Burada şans kaybı (loss of chance ve özellikle perte d'une chance) kavramının tazminat hukukunda uygulanmas1 gündeme gelir. $\mathrm{Bu}$ alanda giderek artan sayıda karar çıkmıştır ve bu kararlarda iyileşme olasılığının kaybı olayı, iyileşme şansının kaybı olarak değerlendirilmekte ve kendisine bir hukuki sonuç bağlanmakta veya bu şekilde en azından tartışılmaktadır. Farklı maddi hukuk ve usul hukuku şartlarına rağmen, davacının, doktorun sorumluluğu davasını başarıyla yürütebilmesi için benzer fikirler ve karşıllaştırılabilecek somut olaylar bu kararlarda yer almıştır. Bununla birlikte, şartlar ve hukuki sonuçlar farklı ve çok yönlü olup hukuk düzenleri içindeki gelişme çoğu zaman aşamalarla gerçekleşir ${ }^{8}$.

\section{A.Tipik Somut Olaylarm Durumu}

Her şeyden önce hatalı veya eksik teşhislerle yok edilen iyileşme şansındaki olası gelişmeler dikkate alınmalıdır. Aşağıdaki farazi dava, değişik hukuk düzenlerindeki çok sayıdaki mahkeme kararında karşılaştırmalı olarak değerlendirilebilir': Bir hasta belirli şikayetleri

${ }^{6}$ Kasche, s. 2.

${ }^{7}$ Bkz. Yargitay 13. Hukuk Dairesi'nin henüz yayımlanmamış olan (10.11.2003 t., E. 2003 / 13964 , K. 2003 / 13347), (16.9.2003 t., E. 2003 /6060 , K. 2003 /10174), (25.12.2003 t., E. 2003 / 10757, K. 2003 / 15490) kararları. Bu kararlar ileride “Türk hukunda durum” başlığı altında değerlendirilmiştir.

${ }^{8}$ Kasche, s. 14.

9 Kasche, s. 14. Konuyla ilgili kararlar - ABD: James v. United States, 483 Federal Supplement (Fsupp) 581 (ND Cal 1980); Herskovits v. Group Health Cooperative of Puget Sound, 664 P2d 474 (Wash 1983); DeBurkarte v. Louvar, 393 NW2d 131 (Iowa 1986); Nevada v. Las Vegas Medical Center, 805 P2d 589 (Nevada 1991); Wollen v. DePaul Health 
yüzünden bir doktora gider. Doktor onu muayene eder ve önemli bir hastalığı olmadığını söyler. Bir süre sonra hastanın sağlık durumu kötüleşir. Yapılan yeni muayenede hastanın akciğerinde ameliyat edilemeyen bir tümör olduğu ortaya çıkar. $\mathrm{Bu}$ durumun ilk doktor ziyareti sırasında kapsamlı bir muayene sonucu ortaya çıkarılmış olması gerekir idi. Doktor burada bir hata yapmıştır. Bununla beraber, tıbbi bilgilere göre daha önceki bir zamanda, ilk doktor muayenesinden sonra yapılan tedavi başarılı olmuş olsa idi, buna benzetilebilen hallerde sadece hastaları \% 30'unda bu safhadaki tümörün iyileştirilebileceği kabul edilir idi. Şimdi hasta öldüğünde ölenin ailesi doktora karşı mahkemede dava açabilirler. Bu muayenenin özenli ve kapsamlı yapıldığını varsaysa idik, yine de hastanın yaşayacağını ispat edemez idik. Tersine, \% 30'luk iyileşme şansı benzer olaylara göre azdır. Bu durum, sebep olma ölçüsüne göre ve ispat yükünün bölüşülmesi dikkate alındığında doktorun ispatlanan kusuruna rağmen açılan davanın başarısız olmasına yol açar. Doğrudan söylemek gerekirse, doktorun sorumluluğunda bu tür davalar tekrar tekrar gündeme gelmektedir; çünkü, hastalığın ilerleme seyrini önceden tahmin etmek çoğu zaman belirsizdir ${ }^{10}$.

\section{B.Çözüm Olanakları}

Doktorların sorumluluğu çerçevesinde tipik durumlar için özel çözümler geliştirilmiştir. Özensiz kanser teşhisi davası ile şu davalar arasında benzerlik kurulabilir: kazadan sonra ihmal edilen muayene tedbirleri ${ }^{11}$, hastalığın veya onun bulgularının teşhis edilememesi ${ }^{12}$,

Center, 828 SW2d 681 (Missouri 1992) - Bu kararla ilgili ayrıntılı bir değerlendirme için bkz. Bruer, Robert S. : "Loss of Chance as a Cause of Action in Medical Malpractice CasesWollen v. DePaul Health Center", 59 Missouri Law Review (MoLRev) 1994, s. 969- 996; Griffett v. Ryan, 443 South Eastern Reporter (Second Series) - SE2d 149 (Virginia 1994); Mayhue v. Sparkman, 653 North Eastern Reporter (Second Series) - NE2d 1384 (Indiana 1995); Kanada: Laferriére v. Lawson [1989] Recueil de Jurisprudence du Québec (RJQ) 27; revsd [1991] Supreme Court Reports (SCR) 541; İngiltere: Judge v. Huntingdon Health Authority [1995] 6 Medical Law Review (MedLRev) 223, QB, bu dava mahkeme dış1 sulh ile bitmiş̧tir: The Guardian , 8 März 1995, S.5 ("Payout for breast cancer blunder").

${ }^{10}$ Kasche, s. 14- 15.

${ }^{11}$ Fransa: CassCiv, 1re, 14.12.1965 Bulletin des arrets de la Cour de Cassation, Chambres Civiles (BullCiv) I No. 707 (S. 541) (Düşmeden sonra dirsek çıkı̆̆ını teşhis etmeme); İngiltere: Hotson v. East Berkshire Area Health Authority [1987] 1 Law Reports - Appeal Cases (AC) 750 , Court of Appeal and House of Lords (CA \& HL) ; sub nom Hotson v. Fitzgerald [1985] 3 AllER 167, QB (Düşmeden sonra kalça yaralanmasının teşhis edilmemesi) ; ABD: Cooper v. Sisters of Charity of Cincinnati, Inc, 272 NE2d 97 (Ohio 1971) (Trafik kazasından sonra eksik muayene). (Kasche, s. 15, dn. 70).

${ }^{12}$ Fransa: CassCiv, 1re, 20.7.1988 JCP 1988 IV 351 (Ateşin ölçülmesinin ihmal edilmesi yüzünden menenjitin teşhis edilememesi ); CassCiv, 1re, 11.10.1988 BullCiv I No 281 (S. 192) (menenjitin kızamıkçık zannedilmesi) ; ABD: Hamil v. Bashline, 392 A2d 1280 (Pennsylvania 1978) (kalp krizinin EKG aracı donanımının eksikliği nedeniyle teşhis edilememesi); Aasheim v. Humberger, 695 P2d 824 (tümörün teşhis edilememesi); McKellips 
aktarılması gereken önemli bilgilerin aktarılmamas1 ${ }^{13}$, önceden alınması gerektiği bildirilen önlemlerin ve emniyet tedbirlerinin alınmasının ihmali ${ }^{14}$ davaları. $\mathrm{Bu}$ davalarda ortak olan, doktorun ihmali yüzünden yapılan tedavinin olası en erken zamanda yapılamamış olması ve zamanın geçmesi yüzünden başarı şansının azalmasıdır ${ }^{15}$. Burada incelenen hukuk düzenlerinde bu davaları ele alan yargısal kararlar, çok yönlüdür ve bu nedenle ayrıntılı olarak ele alınmalıdır. Önerilen çözümler aşağıda ana hatlarıyla anlatılmıştır.

\section{1.İspatın Kolaylaştırılması}

Bazı mahkemeler, buradaki örnek davalara benzer davalarda ispatın kolaylaştırılmasını uygun bulmuşlardır ${ }^{16}$. Buna göre, doktorun kendi kusuruyla iyileşme şansını kaybettirmesi halinde ve bu kusur olmasaydı tamamen iyileşmenin olacağı ispatlanamıyor bile olsa, belirli şartlar altında ispat kolaylaştırılır. Seçilen örnekte davacı, kendisine benzetilebilen davalarda \% 30 iyileşme şansı olduğunu ispatlayabilirse, davada başarılı olmuş sayılacaktır. Böylece davacı, hastanın ölümü nedeniyle ortaya çıkan tüm zararı tazmin ettirebilecektir ${ }^{17}$.

\section{Bağımsız Bir Zarar Olarak İyileşme Olasılı̆̆ı}

Davacının kesin zararının sebebini ve iyileşmenin olmamasını ispatlaması yerine, diğer mahkemeler, doktorun iyileşme olasılığını yok ettiğini ve bu yüzden zararın tazmin edilmesi gerektiğini kabul etmişlerdir ${ }^{18}$. $\mathrm{Bu}$ olasılık, iyileşme şansı olarak adlandırılmaktadır ve kesin zarardan, böylece ölümden veya hayatta kalanların sağlığına zarar vermeden ayrılır ${ }^{19}$.

v. Saint Francis Hospital, Inc, 741 P2d 467 (Oklahoma 1987) (kalp krizinin mide iltihab1 zannedilmesi) ; Scafidi v. Seiler, 574 A2d 398 (NJ 1990) (vakitsiz doğum sancılarının teşhis edilememesi nedeniyle erken doğan bebeğin ölümü). (Kasche, s. 15, dn. 71).

${ }^{13}$ James v. United States, 483 Fsupp 581 (ND Cal 1980).

${ }^{14}$ Fransa: Cour d'appel de Paris, 1re, 10.3.1966, JCP 1966 II 14753 (2. Fall) (R.Savatier) . ABD: Falcon v. Memorial Hospital, 462 NW2d 44 (Michigan 1990); Chambers v. RushPresbyterian- St. Luke's Medical Center, 508 NE2d 426 (III App 1987). (Kasche, s. 15, dn. 73).

${ }^{15}$ Kasche, s. 15-16.

${ }^{16}$ Burada, her şeyden önce ABD mahkeme kararları söz konusudur : Arizona: Thompson v. Sun City Community Hospital, Inc, 688 P2d 605(Arizona 1984); District of Columbia: Daniels v. Hadley Memorial Hospital, 566 F2d 749 (DC Cir 1977), Illionis : Northern Trust Company v. Louis A. Weiss Memorial Hospital, 493 NE2d (IIIApp 1986); Indiana: Mayhue v. Sparkman, 653 NE2d 1384 (Indiana 1994); Pennsylvania : Hamil v. Bashline, 392 A2d 1280 Pennslyvania 1978).

${ }^{17}$ Kasche, s. 16.

${ }^{18}$ Kasche, s. 16. Fransa : CassCiv, 1re, 14.12.1965 BullCiv I No 707; 18.31969 BullCiv I No 117; 17.11.1970 BullCiv I No 301; 25.5.1971 BullCiv I Nos 171-172; ABD: Herskovits Group Health Cooperative of Puget Sound, 664 P2d 474 (Washington 1983).

${ }^{19}$ Herskovits v. Group Health Cooperative of Puget Sound, 664 P2d 474, 481 (Washington 1983); Andel, P.L. : "Medical Malpractice : The Right to Recover for tle Loss of a Chance of 
Bundan sonra, iyileșme şansının değeri, düzenli olarak hastanın ölümünden doğan tüm zararla bir tutulamaz ${ }^{20}$.Tersine, iyileşme olasıllğını, kesin zarardan ayıran burada bağımsız bir zarar kaleminin söz konusu olmasıdır. $\mathrm{Bu}$ değerin hesaplanması farklı biçimlerde yapılır ve genellikle mahkemeler istatistiklere dayanarak iyileşme olasılı̆̆ını kesin zararla orantı kurarak bulurlar. Tahmini iyileşme olasıllı̆ $1 \%$ 30'u buluyorsa, kesin zararın \% 30’u tazmin edilecektir. Bu nedenle, bu denklemin kurulmasında belirleyici olan, bağımsız değer iyileşme şansına dayandırılır dayandırılmaz (genellikle orantılı olarak) indirilmiş bir tazminatın verilmesidir ${ }^{21}$.

Yargısal kararlar, iyileşme şansının kaybına sadece ispatın kolaylaştırılmasını bağlamakla yetinmemiş, aynı zamanda burada tazmin edilmesi gereken bir zarar durumu olduğunu kabul etmiștir. Bununla, ispat hukukuna ilişkin atılıma kıyasla, iyileşme şansının kaybının hukuki nitelendirilmesinde önemli gelişmeler belirlenmiştir. İlk olarak Fransa'da iyileşme şansının kaybının tazmin edilebileceği görüşü kabul etmiştir.ABD'deki bazı yargı kararlarında da aynı görüş kabul görmüştür. Bu gelişmenin, her defasında, diğer hukuk düzenlerinden bağımsız olarak gerçekleştirilmesi dikkate değerdir. Diğer hukuk düzenlerinde iyileşme şans1 incelenmemiştir; fakat en azından etkisi bakımından karşılaştırılabilecek bazı at1limlar vardir ${ }^{22}$.

İyileşme şansının bağımsız bir zarar olarak kabul edilmesi, ilk defa Fransa'da olmuştur. Bu ülkedeki mahkemeler, 60'lı yıllarda iyileşme şansının kaybını (perte d'une chance de guérison) kabul etmiştir ${ }^{23}$.

İlk defa Grenoble İstinaf Mahkemesinin (Cour d'Appel de Grenoble) yayımlanmamış bir kararında bu yeni eğilim ortaya çıkmışıır ${ }^{24}$. Bu davada, davacı el bileğinin yaralanmasından acı çekmekteydi.Yapılan röntgen incelemesinde el bileğinin kırıldığı doktor tarafından teşhis edilemedi ve bu nedenle tedavi edilemedi. Davacı, daha sonra el bileğini yeniden kırdı. Yeniden kırılan bileğin tedavisi sırasında eski röntgenler tekrar çekildi ve ilk tedavide daha önceki bilek kırılmasının teşhis edilmesi gerektiği belirlendi. Davacının ileri sürdüğü gibi, hatalı teşhisin ve buna bağlı olarak tedavinin ihmal edilmesinin yeni yaralanmaya yol açtığ 1 kesin olarak ispatlanamamıştır. Diğer taraftan, davacının iddia ettiği gibi ihmal edilen

Survival”, 12 PeppLRev 973-998, 986 (1985); Kasche, s. 16-17.

${ }^{20}$ Herskovits v. Group Health Cooperative of Puget Sound, 664 P2d 474 (Washington 1983);

DeBurkarte v. Louvar, 393 NW2d 131 (Iowa 1986); King, J.H. : "Causation, Valuation and Chance in Personal Injury Torts Involving Preexisting Conditions and Future Consequences", 90 Yale LJ 1353- 1397 (1981); Giesen, D. : Anmerkung zu OLG Köln, 30.5.1990 27 U 169 / 89 JR 1991, 460 (465); Kasche, s. 17.

${ }^{21}$ Kasche, s. 17.

${ }^{22}$ Kasche, s. 119.

${ }^{23}$ Kasche, s. 119.

${ }^{24}$ Kasche, s. 119; RTDC 1963 (61) 326- 363 (334-335). 
tedavinin sonradan ortaya çıkan dolaylı zarar üzerinde hiçbir etkisi olmadığının düşünülmesi mümkün değildir. Mahkem, kararını verirken, orta bir yol izlemiştir. Mahkeme, önce ihmal edilen tedavi ile el bileğinin yeniden kırılması arasındaki illiyet bağının ispatlanamadığını belirtmiştir. Ancak, mahkeme, davacının zamanında yapılan tedaviyle iyileșebilme ve böylece yeni bir yaralanma ihtimalinin önlenebilme şansını kesin olarak kaybettiğini (perte d'une chance de guérison) kabul etmiştir. Bu kayıp, tazmin edilmesi gereken tek zarardır ${ }^{25}$.

\section{Geleneksel Ölçütlerde Israr Etmek}

$\mathrm{Bu}$ denklem kurmanın yanısıra, iyileşme şansının kaybının hukuki öneminden hareketle illiyet bağı ölçütlerinde ısrar edilerek davacının zararının tazmin edilmemesi olasılığ $\mathrm{da} \operatorname{vardır}^{26}$.

\section{Diğer Önlemler}

İyileşme şansı kurumunun bulunmadığı hukuk düzenlerinde de çözülmesi gereken benzer somut olaylar vardır. Alman doktorların sorumluluğu davalarının merkezinde ispat yükünün ters çevrilmesine kadar varan ispatın kolaylaştırılması bulunmaktadır. Fakat, bunlar uygun olamayan ve eksik teşhis ve tedavilerin iyileşme şansını azaltmasına bağlanmamaktadır, tersine Alman mahkemeleri tarafından geliştirilen, ağır tedavi hatalarına veya muayeneden elde edilen sonucun teminat altına alınması yükümlülüğünün ihlâlinin belirlenmesi haline bağlanmaktadır. Tedavi eden doktorun eksik bilgisiyle ortaya çıkan kanser şüphesi ${ }^{27}$ ve aynı şekilde kalp enfarktüsü ${ }^{28}$ bulgusunun yanlış yorumlanması, ağır bir tedavi hatası olarak sınıflandırılmaktadır. Sonuç olarak, kesin zarara (kanser hastalığının kötüleşmesi, kalp enfarktüsünden ölüm) neden olan ispat yükü ters çevrilmiştir, böylece doktor doğan bu zararı karşılamak zorundadır ${ }^{29}$.

\footnotetext{
${ }^{25}$ Kasche, s. 119 - 120. Bu kararla ilgili açıklama ve değerlendirmeler için ayrıca bkz. Großerichter, Helge : Hypothetischer Geschehensverlauf und Schadensfeststellung, Eine rechtsvergleichende Untersuchung vor dem Hintergrund der perte d'une chance, München 2001, s. 132.

${ }^{26}$ Kasche, s. 17.

${ }^{27} \mathrm{BGH}, 24.4 .1989$ VI ZR 175 / 88 BGHZ 107, 222.

${ }^{28}$ BGH, 13.2.1996 VI ZR 402 / 94 BGHZ 132, 47; bu karar özellikle ilginçtir; çünkü eksik EKG sonucu yüzünden muayeneden elde edilen sonucun teminat altına alınması yükümlülüğünün ihlâli söz konusudur. Burada doktorun mevcut olan enfarktüs bulgularını açıklama yükümlülüğünün olduğu şüphesizdir. Bu bulguların yanlış yorumlanması, ağır bir tedavi hatası olup, ispat yükünün ters çevrilmesi sonucunu doğurur.

${ }^{29}$ Kasche, s. 17-18.
} 


\section{II.Doktorun Sorumluluğunun Esasları}

İyileşme şansının hukuki önemiyle ilgilenen hukuk düzenlerinde, doktorun sorumluluğunun maddi hukuk ve usul hukuku nedenleri bakımından geliştirilen ve biraz önce esas hatlarıyla anlatılan çözüm olanakları bulunmaktadır.

\section{A.Talebin Esaslart ve Şartlart}

\section{Sözleşme Sorumluluğu}

Bir tarafta tedavi eden doktor, özellikle hastane, diğer tarafta hastanın olduğu bir tedavi sözleşmesi söz konusudur, bu yüzden sözleşme sorumluluğu hesaba katılmalıdır. Burada incelenen bütün hukuk düzenlerinde kural olarak sözleşmesel sorumluluk mümkündür ${ }^{30}$.

\section{a) "Common law" sisteminde}

Doktor ve / veya hastane ile hasta arasında sözleşmesel bir bağlantı mevcuttur.Her şeyden önce, bir sözleşmenin ihlâli, kusurdan bağımsız bir talep olan "breach of contract" ile anlatılmalıdır" ${ }^{31}$. Gerçekte İngiltere'de sözleşmesel talep sadece ikinci derecede bir öneme sahiptir; çünkü, hastaların çoğu "National Health Service" çerçevesinde tıbbi tedavi talebinde bulunurlar. Bu kamu araçlarıyla finanse edilen sağlık sistemi hasta için karşılıksızdır ve sözleşmesel sorumluluğun hesaba katılmamasına neden olur $^{32}$. Bu suretle, İngiltere'de sadece özel hastalar sözleşmesel talebe dayanabilir. Fakat, Anglo Amerikan hukuk çevresindeki kararların çoğunda sözleşmesel değil, tersine haksız fiil talepleri ön plandadır ${ }^{33}$. Bu durum, sözleşmenin varlığından bağımsız olarak kabul edildiği ve tazminatı doğuran haksız fiilin unsurlarından ihmale (negligence) göre, özen yükümlülüğ̈̈nün ihlâline dayandığı için bir sözleşme yapmak gerekli görülmez ${ }^{34}$. Ayrıca, common law hukuk düzeninde, zımni olarak kararlaştırılan sözleşme şartlarının (implied terms) kabulü hususunda çekingen ${ }^{35}$ davranılmaktadır ve sözleşme hukuku her zaman uygun ve yeterli bir talebin esası olarak anlaşılmamaktadır ${ }^{36}$.

\footnotetext{
${ }^{30}$ Kasche, s. 18.

${ }^{31}$ Giesen, D. : "Zur Konstruktion englischer Vertragsvereinbarungen”, JZ 1993, s. 16-24.

${ }^{32}$ Giesen, D. : International Medical Malpractice Law (1988), Rn. 10.

${ }^{33}$ Kasche, s. 18-19.

${ }^{34}$ Kozan v. Comstock, 270 F2d 839, 844 (5th Cir 1959); Yepremian v. Scarborough General Hospital (1980) 13 Canadian Cases on the Law of Torts (CCLT) 105, 174 Ontario Court of Appeal (Ont CA); Giesen, Rn. 30 - 31; Kasche, M. : "Operation in Australien", Jura 1993, ( s. 94- 103) s. 101.

${ }^{35}$ Giesen, Zur Konstruktion, s. 18.

${ }^{36}$ Kozan v Comstock, 270 Federal Reporter (Second Series - F2d) 839, 844 (5 th Cir 1959); Yepremian v. Scarborough General Hospital (1980) 13 CCLT 105, 174 (Ont CA); Kasche, s. 19.
} 


\section{b)Fransız hukukunda}

Fransa'da öncelikli sorumluluk sebebi, sözleşmedir; çünkü, hakların yarışması çerçevesinde haksız fiil sorumluluğu hesaba katılmamaktadır ${ }^{37}$. Bir sözleşme varsa, bu sözleşmenin yanısıra genel haksız fiil kurallarının hesaba katılması mümkün değildir; çünkü bu durum, sözleșme özgürlüğüne ters düşer ${ }^{38}$. Doktor, bütün yeteneklerini, olanaklarını ve araçlarını kullanarak hastaya yardım etmek için çaba göstermekle yükümlüdür. Doktorun bu yükümlülüğü obligations de moyens ${ }^{39}$ ad1 altında anılır. Burada, obligation de résultat ${ }^{40}$ kavramından farklı olarak, sonuç değil, tersine, sadece bu sonuca ulaşmak için gösterilmesi gereken çaba borçlanılmıştır. $\mathrm{Bu}$ ayırım, sözleşmenin ihlâli halinde sorumluluğun sonuçları bakımından da önem taşır. Obligation de résultat kavramında çabalanan sonucun ortaya çıkmaması halinde kusurun varlığg varsayılır ${ }^{41}$. Obligation de moyens kavramında ise, davacı az da olsa bir kusurun varlığını ispatlamak zorunda olup, sonucun ortaya çıkmaması, davalının sorumluluğu için yeterli değildir; çünkü, davalı bunun için kimseye borçlanmamıştır. Hasta, doktorun çabalarının kusursuz olmadığını ispatlamak zorundadır ${ }^{42}$.

\section{c)Alman hukuk çevresinde}

$\mathrm{Bu}$ çevrede, doktorun sorumluluğu bakımından sözleşme sorumluluğunun kabul edilmesi mümkündür. Ancak, buradaki sorumluluk, istisna sözleşmesi anlamında sonuca ulaşma şeklinde değildir. Tersine, Almanya ve Avusturya'da doktorla hasta arasında yapılan sözleşme hizmet sözleşmesidir ${ }^{43}$. İsviçre'de ise, doktorla yapılan bu sözleşme vekâlet sözleşmesi ${ }^{44}$ olarak düzenlenmiştir. Ayrıca, hastanede tedavi sırasında

${ }^{37}$ CassCiv, 20.5.1936 D $1936 \mathrm{~J} 88$.

${ }^{38}$ Giesen, Rn. 48.

${ }^{39}$ CassCiv, 20.5.1936 J 88; Penneau, $J$ : Medical Responsibility in Western Europe : France (1985) Rn. F 41, F 48 - F 51; Giesen, Rn. 12; Kasche, s. 19. Belli alanlarda Obligations de résultat kavramıyla aşağı yukarı aynı olan kavramlar için bkz. ve karş. Sargos, Pierre : "Reflexions sur les accidents médicaux et la doctrine jurisprudentielle de la Cour de cassation en matiére de responsabilité medicale", D 1996, Chron, 365-370; Viney, Geneviéve / Jourdain, Patrice. : "L'indemnisation des accidents médicaux: que peut faire la Cour de cassation?”, JCP 1997 I 4016.

${ }^{40}$ Ferid, M. / Sonnenberger, H. J. : Das französische Zivilrecht, Band 2, (1986) 2 K 121 (S. 288).

${ }^{41}$ Kasche, s. 19.

${ }^{42}$ Giesen, Rn.12; Kasche, s. 19.

${ }^{43}$ Giesen, D. : Arzthaftungsrecht (1995), Rn. 7; Laufs, A. : Arztrecht, 3. Aufl., München 1984, s. 25; Deutsch, E. / Matthies, K.H. : Arzthaftungsrecht, Grundlagen, Rechtsprechung, Gutachter und Schlichtungsstellen, Köln 1987, s. 9-10; Ott, W. E. : Voraussetzungen der zivilrechtlichen Haftung des Arztes, Zürich 1978, s. 23.

${ }^{44}$ Honsell, H. : Handbuch des Arztrechts (1994), s. 22-23; Ott, s.23; Kuhn, M. : Die Entwicklung in der Haftpflicht des Arztes, ZSR, N.F. 105, 1986, I. Halbband, s. 472-474; Loeffler, W. : Die Haftung des Arztes aus ärztlicher Behandlung, Zürich 1945; Schroeder, Karl : Probleme der zivilrechtlichen Haftung des freipraktizierenden Zahnarztes, Zürich 
hastayla yapılan sözleşmenin tarafının sadece hastane mi olduğu veya onun yanısıra tedavi eden doktorun da sorumlu tutulup tutulamayacağı, sözleşmenin yorumuyla açıklığa kavuşturulabilirr ${ }^{45}$.

d) O halde, sözleşme sorumluluğunun büyük ve farklı bir önemi vardır. $\mathrm{Bu}$, bir taraftan sağlığın sağlanmasının farklı bir şekilde düzenlenmesine, diğer taraftan da sözleşme ve haksız fiil hukuklarının yapısına dayanır. Bir sözleşme varsa, hasta, sözleşmedeki hükümleri ihlâl eden ve bu şekilde zarara sebep olan doktor aleyhine dava açarak ileri sürdüğü zararını bütün hukuk düzenlerinde tazmin ettirebilir. Elde edilmeye çalışlan iyileşme sonucuna ulaşılamaması, bir sorumluluğun doğmasına neden olmaz ${ }^{46}$.

\section{Haksız Fiil Sorumluluğu}

Haksız fiil sorumluluğu, burada incelenen hukuk düzenlerinde farklı düzeylerde öneme sahiptir. Bu, her şeyden önce, farklı anlaşılan, sözleşmeye ve haksız fiile dayanan taleplerin yarıştığını gösterir; fakat her talep kendi şartlarına uygun olarak yerine getirilmelidir ${ }^{47}$.

a) Common law sisteminde, doktorun sorumluluğunun merkezinde haksız fiilin unsurlarından ihmal (negligence) vardır ${ }^{48}$. Bu unsurdan, kasitlı olmaksızın, özen yükümlülüğü bakımından görevin ihmali anlaşılır. Doktorla hasta arasında varolan özen yükümlülüğü (duty of care) ${ }^{49}$, bakımından görevin ihmali, doktorun göstermesi gereken özen ölçüsünü gösteremeyip ihlâl etmesi (breach of duty) ${ }^{50}$ ve buna bağlı olarak hastaya bir zarar vermesi (consequent damage) ${ }^{51}$ ile kasıtlı olmaksızın gerçekleştirilmiş olur $^{52}$. Bunun yanısıra, kasitlı olarak hastanın rizasını almaksızın doktorun verdiği bedeni zarar (battery) da dikkate alınmalıdır ${ }^{53}$. Ancak, bu sorumluluk, hastanın rızasının olmadığı olaylarla sınırlıdır. Doktorun eksik

1982, s. 21; Nägeli, Max : Die äztliche Behandlung handlungsunfähiger Patienten aus zivilrechtlicher Sicht, Zürich 1984, s. 71; Merz, Barbara: Analyse der Haftpflichtsituation bei Schädigung durch Medikamente, Zürich 1980, s. 62; Frank, Richard : Persönlichkeitsschutz heute, Zürich 1983, s. 174; Stürner, Rolf : Die schweizerische Arzthaftung im internationalen Vergleich, SJZ 1984, (s. 121-130) s.122.

${ }^{45}$ Kasche, s. 20; Schmid, E. M. : Die Passivlegitimation im Arzthaftpflichtprozeß (1988) 83; ayrica bkz. Kasche, "Operationen in Australien”, Jura 1993, 94-103 (98).

${ }^{46}$ Kasche, s. 20.

${ }^{47}$ Kasche, s. 20.

${ }^{48}$ Giesen, Rn. 38-40.

49 Lord Atkin'e göre, bu konuda "neighbour test" olarak adlandırılan testin de bilinmesi gerekir (Donoghue v. Stevenson [1932] AC 562, 579). Ayrıntılı bilgi ve karşılaştırmalı hukuk bilgisi için bkz. Giesen, Rn. 109- 126.

${ }^{50}$ Giesen, Rn. 127- 139.

${ }^{51}$ Giesen, Rn. 268-305; Kasche, s. 20.

${ }^{52} \mathrm{Bu}$ şartların uygulanmasını karș. Kasche, M. : "Operation in Australien”, Jura 1993, (s.94103) s. 94-96.

${ }^{53}$ Giesen, Rn. 35-36; Kasche, s. 20-21. 
açıklamasıyla alınan rıza, yukarıda söz edilen battery kavramının kapsamı dışındadır ${ }^{54}$. Aslında, bu talebin uygulama alanı sınırlandırılmışıır ${ }^{55}$.

b)Fransız hukukunda, doktorun sorumluluğunda, sözleşme ve haksız fiil arasında hakların yarışması söz konusu olmaz ${ }^{56}$. Doktorun ve özellikle hastanenin haksız fiil sorumluluğu, aynı zamanda hastayla aralarında bir sözleşme olması halinde farklılık gösterir.Böylece, haksız fiil sorumluluğu, her şeyden önce, tazminatın doktordan talep edildiği ve hastanenin sadece sözleşmenin tarafı olduğu durumlarla sınırlıdır ${ }^{57}$.

c)Almanya'da doktorun haksız fiil sorumluluğu, her şeyden önce $\S 823$ f.1 BGB'ye dayanmaktadır. Doktorların tedavi önlemleri arasında, sadece hastanın geçerli rızasının haklı çıkarabileceği, somut olaydaki duruma göre ölçülü bedensel zarar verme ${ }^{58}$ görülmektedir. Rızanın geçerli sayılabilmesi için doktorun açıklamasının tedaviden doğabilecek riskleri de kapsaması gereklidir, yoksa hastanın sadece doktorun müdahalesi için muvafakat göstermesi yeterli değildir ${ }^{59}$. Haksız fiil sorumluluğunun pratik önemi, her şeyden önce sözleșme sorumluluğundan farklı olması ve aynı zamanda manevi tazminat (Schmerzensgeld) sonucunu da doğurmasıdır ( $\$ 847$ BGB ) ${ }^{60}$. Avusturya'da haksız fillerin talebinin esasını $§ 1299$ ABGB ve İsviçre'de ise Art. 41 OR oluşturur ${ }^{61}$.

d)Common law sisteminde ve Alman hukuk çevresinde, doktorun sorumluluğu bakımından haksız fiil hukuku belirleyici bir rol oynamaktadır. Doktorun özen yükümlülüğünün ihlâlinin yanısıra, her defasında hastanın sağlığına zarar verilmesine neden olma da şarttır. Bu durum, hasta ile doktor arasında hiçbir sözleşmenin mevcut olmadığı Fransız hukuku bakımından da geçerlidir. § 823 f.1 BGB'nin yapısal özelliği, sadece orada sayılan kişi varlığı haklarının korunmasıdır. Bundan dolayı, haksız fiil hukukunun korunmasını sadece belirli kişi varlığı hakları ile sınırlamayan hukuk düzenlerinden farklı olarak, Alman hukukunda korunması gereken yeni türdeki varlıkları bu maddeye dahil etmek büyük zorluklara yol açmaktadır. Ayrıca, common law sisteminde, bir taraftan kişi varlığı haklarının ihlâliyle,

${ }^{54}$ Kasche, s. 21. Konuyla ilgili kararlar : İngiltere: Sidaway v. Bethlem Royal Hospital [1985] 1 AC 871, 883, Avustralya : F V R (1983) 33 SASR 189, 190 (FC); Ellis v. Wallsend District Hospital (1989) 17 NSWLR 553, 578 (CA); Kanada: Reibl v. Hughes [1980] 2 SCR 880; ABD hukukunda bu konuyla ilgili açıklamalar için bkz. Robertson, G. : "Informed Consent to Medical Treatment”, (1981) 97 Law Quarterly Review (LQR) 102- 126 (104-105, 124-125).

${ }^{55}$ Kasche, s. 21.

${ }^{56}$ Giesen, Rn. 48-49.

${ }_{58}^{57}$ Giesen, Rn. 49; Kasche, s. 21.

${ }^{58}$ Kötz, Hein : Deliktsrecht, 7. Aufl., Neuwied, Kriftel 1996, Rn.96; Laufs, A. : Arztrecht, 1993, Rn. 174 (karşıt görüşlere de yer vermiş ve çeşitli kanitlar üzerinde durmuştur).

${ }^{59}$ Laufs, Rn.185-189; Kasche, s. 21.

${ }^{60}$ Kasche, s. 21. BGB § 847 yürürlükten kaldırılmıștır. Bkz. Bürgerliches Gesetzbuch (BGB), 53. Aufl. , München 2003, s. 261 (Beck- Texte im dtv).

${ }^{61}$ Giesen, Arzthaftungsrecht, Rn. 23. 
diğer taraftan bundan çıkan sonuç arasında farklı olan, başka yerlere uymayan, nedensellik bağının sadece bir kere incelenmiş olması ve Almanya'dakinden farklı olarak sorumluluğu doğuran veya sorumluluğu tamamlayan olaylar arasinda siniflandirilmamasidir ${ }^{62}$.

\section{3.Ölenin Ailesinin (Hayatta Kalanlarin) Talepleri}

Doktorun sorumluluğunda, hastanın talepleri yanında, ölenin ailesinin talepleri de pratik açıdan büyük önem taşımaktadır. Bu tür talepler iki grupta toplanabilirr ${ }^{63}$ : Bir kere, ölenin ailesi, gerektiğinde ölümden doğan zararları ve özellikle ölenin, sağ kalsa idi, gelecekte elde edeceği ve şimdi ölüm nedeniyle kaldırılan nafaka ödemelerinin tazminini talep edebilir. Bundan başka, ölenin, ölmeden önce, hatalı tedavi nedeniyle açtığı davadan doğan taleplerin miras yoluyla mirasçılara geçmesi de söz konusu olabilir. Burada, ölenin, ölmeden önceki hem maddi tazminat hem de manevi tazminat talepleri söz konusudur. $\mathrm{Bu}$ ayırım, özellikle burada incelenen iyileşme şansının tazmin edilebilmesi ve bunun şartları bakımından önemlidir. Burada, ölenin, ölmeden önceki talepleri söz konusudur, öyleyse talebin bütün şartları, ölümden önce gerçekleşmelidir. İleri sürülen taleplerin tarzı, çıkarsama yoluyla taleplerin şartlarından çıkarılabilir ${ }^{64}$. Bu durum, bir örnekle açıklanabilir : Bir doktor, hastanın iyileşme şansı olmasına rağmen, ihmalli bir şekilde kanser hastalığını teşhis ve tedavi edememiştir. Böylece hastanın ölümünden önce kaybettirilen iyileşme şansı nedeniyle tazminat istemeye hakkı olup olmadığı sorusunun cevabı şüpheli kalmıştır. Bu talep, miras yoluyla geçebilirdi. Hasta, ölene kadar, iyileşme şansının kaybından doğan zararın tazminini içeren böyle bir talepte bulunmamışsa, onun ailesi, ölümünden sonra sadece kendi haklarına dayanarak dava açabilirler ${ }^{65}$.

\section{a.Ölüm Nedeniyle Talepler}

Hastanın ölümü nedeniyle, onun ailesinin destekten yoksun kalma tazminatına ilişkin talebi, burada incelenen hukuk düzenlerinde kabul edilmiştir $^{66}$. Bu hukuk düzenlerinde böyle bir talebin açıklanması, bazı farklıl1klar gösterir ${ }^{67}$.

aa. Olaylar ve örnekler hukukunun (Common law) ilkelerine göre, ölenin ailesinin destekten yoksun kalma tazminatına ilişkin talebi kural

\footnotetext{
${ }^{62}$ Kasche, s. 21-22.

${ }^{63}$ McGregor, $H$. : Personal Injury and Death, International Encylopedia of Comparative Law (IECL) Vol. XI Ch.9 (1972), s. 80-85; Savatier, R. : Anmerkung zu CassCiv, 1re, 1.4.1968 D 1968 J 653; Martin v. East General Jefferson Hospital, 582 Southern Reporter (Second Series)-So2d 1272, 1279 (Louisiana 1991).

${ }^{64}$ Kasche, s. 22 .

${ }^{65}$ Kasche, s. 22.

${ }^{66} \mathrm{Bu}$ konunun ana hatları için bkz. McGregor, H. : Personal Injury and Death, Vol. XI ch. 9 (1972) $85-105$.

${ }^{67}$ Kasche, s. 23.
} 
olarak söz konusu değildir ${ }^{68}$. Bu durumun hakkaniyete aykırı, haksız sonuçlar ortaya çıkarabileceği erken zamanda kabul edildi. Hem İngiltere ${ }^{69}$ hem de ABD'deki çok sayıda federal devlet 19. yüzyılda Wrongful Death Acts adıyla anılan kanunları kabul ettiler. Bu kanunlarla, hastanın ölümüne tedavi hatasının neden olması halinde ${ }^{70}$, ölenin ailesinin kendi haklarına ${ }^{71}$ dayanarak tazminat isteyebilecekleri kabul edildi. Karı kocanın diğerinin evlilik gereği yardımını talep etme hakkının kaybı (loss of consortium) nedeniyle tazminat talebinin $\mathrm{ABD}$ 'de sağ kalan eşin evlilik birliğinin kaybından doğan denkleştirme talebi olarak kabul edilmesi dikkate değerdir ${ }^{72}$. Diğer manevi zararların tazmini, sadece ölümün alışılmış ölçüdeki üzüntüyü çok aştığı ve hak sahibinin sağlı̆̆ına verilen bağımsız bir zarar olarak ortaya çıktı̆̆ altında mümkündür ${ }^{33}$.

bb. Fransız Medeni Kanunu (Code Civil) ölenin ailesinin talepleri ile ilgili açık bir hükme yer vermemiştir. Fakat, bu durum böyle bir destekten yoksun kalma tazminatına ilişkin talebin olmadığı anlamına gelmez. Fransız yargısal kararları, böyle bir talebin haksız fillerle ilgili genel hüküm olan Fransız Medeni Kanunu'nun 1382. maddesine dayandırılabileceğine karar verdiler $^{74}$. Doktorla ölen hasta arasında bir tedavi sözleşmesinin varlığ halinde, haksız fiilden doğan bu talep, doktorun sorumluluğu hukuku bakınından da uygulama alanı bulur ${ }^{75}$. Bu nedenle, non cumul ilkesi, haksız fiil sorumluluğunu sadece sözleşmenin tarafları arasında dikkate almamaktadir ${ }^{76}$.

cc. Alman Medeni Kanunu (BGB) § 844 f.2'de ölenin yakınlarının destekten yoksun kalma tazminatına ilişkin talepleri açikça düzenlenmiştir.

\footnotetext{
${ }^{68}$ Kasche, s. 23. Baker v. Bolton (1808) 1 Campbell Nisi Prius Reports (Camp) 493, KB; Admiralty v. SS Amerika [1917] AC 38.

${ }^{69}$ Fatal Accident Acts 1846; Şimdi bu Kanunun yerine yürürlüğe konan Fatal Accidents Act 1976 ile değiştirilmiştir (Kasche, s. 23, dn. 109).

${ }^{70}$ Wollen v. De Paul Health Center, 828 SW2d 681, 685 (Missouri 1992) . Bu kararla ilgili ayrıntılı bir değerlendirme için bkz. Bruer, Robert $S$. : "Loss of Chance as a Cause of Action in Medical Malpractice Cases - Wollen v. De Paul Health Center", 59 Missouri Law Review 1994, s. 969 - 996.

${ }^{71}$ United States v. Cumberbatch, 647 A2d 1098, 1103 (Delaware 1994).

${ }^{72}$ Kasche, s. 23. Roseberry v. Starkovich, 387 P2d 321 ( New Mexico 1963); Peeples v. Sargent, 253 NW 2d 459, 471 (Wisconsin 1977).

${ }^{73}$ Alcock v. Chif Constable of South Yorkshire [1992] 1 AC 310; Kasche, s. 23.

${ }^{74}$ Cass Civ 1re, 1.4.1968 D 1968 J 653 (R. Savatier) ; 25.5.1971 D 1972 J 534 (J. Penneau); Roma hukuk çevresindeki diğer hukuk düzenlerindeki gelişmeler için bkz. McGregor, s. 8586.

${ }^{75}$ Kasche, s. 23-24 . CassCiv, 1 re, 1.4.1968 D 1968 J 653 (R. Savatier) ; 25.5.1971 D 1972 J

534 (J. Penneau) ; Penneau, J. : Medical Responsibility in Western Europe : France (1985)

Rn. F 47.

${ }^{76}$ Kasche, s. 23- 24.
} 
Benzer düzenlemeleri İsviçre'de ${ }^{77}$, İsviçre Medeni Kanunu (OR) m.45 f.3'de ve Avusturya' da ${ }^{78}$, Avusturya Medeni Kanunu (ABGB) m.1327'de bulmak mümkündür. Ölenin yakınlarının manevi tazminat talebinin Avusturya ${ }^{79}$ ve Almanya' $\mathrm{da}^{80}$ kural olarak ${ }^{81}$ kabul edilmemesine karşın, İsviçre'de böyle bir tazminat talebinin İsviçre Medeni Kanunu (OR) m.47'ye ${ }^{82}$ göre mümkün olması dikkate değerdir.

\section{b. Hakların Geçişi}

aa.Maddi tazminat ve manevi tazminat taleplerinin mirasçılara geçişi hakkında common law özel bir konuma sahiptir; çünkü ölenin ölümünden sonra hakları ve borçlarının mirasçılara geçmesi mümkün değildir ${ }^{83}$. Böyle bir geçiş (survival of actions) daima imkânsızdır. Ölenin ailesi, örneğin ölenin ölmeden önce açtı̆̆ 1 davada ileri sürdügü manevi tazminat talebini artık onun ölümünden sonra dava edemezler. Tersine, böyle talepler ölene zarar veren kişinin terekesine karş1 da ileri sürülemez ${ }^{84}$. Common law yargısal kararlarının büyük kısmı, kanunkoyucuyu kanun dolayısıyla bu hakların devam ettirilmesini düzenlemekle görevlendirmiștir ${ }^{85}$. Bu, terekenin (estate) zarar verene karşı belirli önlemler alması anlamına gelir. Tersine, ölünün terekesine karşı da böyle talepler ileri sürülebilir. Burada, common law miras hukukunun özelliği ortaya çıkmaktadır. Bu hukuk sistemine göre, miras, mirasçılara evrensel halefiyet sistemiyle geçmemektedir, tersine her şeyden önce bağımsız hukuki bir mal yığını oluşturur ${ }^{86}$. Bundan dolayı, ölenin yakınları için ölümden doğan sonuçlar tazmin edilmez, tersine hastanın ölümünden önceki uğradığı zararlar tazmin edilir ${ }^{87}$.

bb)Buna karşıllk, Fransa'da taleplerin geçişi Medeni Kanun'un 718. maddesinde düzenlenmiştir ve hiçbir problem yaratmamaktadır ${ }^{88}$.

\footnotetext{
${ }_{78}^{77}$ Buna ilişkin olarak bkz. OR I (A.K. Schnyder) Art. 45 OR, Rn. 7-12.

${ }^{78} \mathrm{Bu}$ konuyla ilgili bkz. Rummel, Peter: Kommentar zum Allgemeinen bürgerlichen Gesetzbuch 2. Band $\S \S 1175$ bis 1502 ABGB; Nebengesetze, 2. Aufl., Wien 1992 (R.Reischauer) § 1327 ABGB, Rn. 1-4, 21.

${ }^{79}$ Rummel, P. (Reischauer, R.) § 1327 ABGB, Rn. 4; Kasche, s. 24.

${ }^{80}$ Kötz, Hein : Deliktsrecht, 7.Aufl., Neuwied, Kriftel 1996, Rn. 529.

81 Ölenin yakınlarının manevi tazminat taleplerinin kabul edilip edilmeyeceğinin tartışmalı olduğu haller için bkz. Kötz, Rn. 51-53.

${ }^{82}$ Kasche, s. 24. Bu konuda ayrica bkz. OR I (A.K.Schnyder) Art. 47 OR,Rn. 1-12.

${ }^{83}$ Kasche, s. 24; Winfield, P.H. : "Death as Affecting Liability in Tort" , 29 Columbia Law Review (ColLRev) 239- 254 (1929).

${ }^{84}$ Kasche, s. 24; Winfield, s. 239- 254.

${ }^{85}$ Kasche, s. 24.

${ }^{86}$ Henrich, Dieter : Einführung in das englische Privatrecht, 2. Aufl., Darmstadt 1993, s. 104 , 105, 110; Kasche, s. 24- 25;

${ }^{87}$ Kasche, s. 25. Wollen v. DePaul Health Center, 828 SW2d 681, 685 (Missouri 1992). Burada ayrıca zarar görenin "loss of expectation of life" olarak adlandırılan bir talebi daha vardır ve artık kanun değişikliği nedeniyle kaldırılmıştır (Giesen, Rn. 454 - 455).

${ }^{88}$ Kasche, s. 25.
} 
cc)Ölenin, maddi tazminat taleplerinin mirasçılarına geçmesi, evrensel halefiyet ilkesine göre, Alman hukuk çevresinde, § 1922 BGB, Art. 560 ZGB ve özellikle $\S 532$ ABGB'de serbest bırakılmıştır. Her şeyden önce manevi tazminat taleplerinin geçişi sorunludur. Çünkü manevi zararların mirasçıya geçmesi ancak belli koşullar altında mümkün olabilir ${ }^{89}$. Yakın tarihte Avusturya Yargıtay'ı da mirasçılara böyle bir talebin geçişini kabul etti ${ }^{90}$. Buna karşı, İsviçre'de md. 47 OR ölenin yakınlarının bağımsız bir talebini öncelikli olarak kabul etmiştir ${ }^{91}$.

\section{IV.İsviçre'deki Durum}

\section{A.Genel Olarak}

Hayatta kalma veya iyileşme şansının tazmin edilme vasfı, yabancı hukuklarda çok tartışmalıdır. Fransız, Amerikan, Belçika ve Hollanda kazai içtihatları bu anlamda oldukça olumlu olarak tespit edilmişlerdir. Alman ve Kanada hukukları, iyileşme veya hayatta kalma şanslarının tazminini reddetmektedirler ve İngiliz hukuku ise yoruma açık bir konum almaktadır. $\mathrm{Bu}$ çalışma, kayıp olmuş tıbbi şansların tazmini firsatını tartışmıştır ve bu konunun İsviçre hukukunda aynı olması sonucuna varmıştır. KOZIOL, bunun aksine, İsviçre Borçlar Kanunu'nun 44/ I maddesi sayesinde, sorumluluğu ortaya çıkaran bir olay ile zarar veren sonuçların mağdur tarafından katlanılması gereken tesadüfi bir durumun ortaya çıkışı arasında alternatif nedenselliği uygulayarak mağdurların zararını kısmen tazmin etmeyi önermektedir. Bununla beraber, bu önerinin İsviçre hukukunda kendini kabul ettirmesinin zor olacağına inanmaktadır, zira alternatif faillerin müteselsil sorumluluğu çoğunlukla reddedilecektir, yalnız faillerin birlikte hareket edecekleri durum bundan istisnadır. GROSS ise, kaybedilmiş olan şanslar gerçek ise, tamamen; gerçek dıșı değillerse veya tamamen farazi değillerse, tıbbi konuda bir şansın kaybının tazmin edilmesi gerektiğini düşünmektedir. Doktor tarafindan yetersiz bilgi verilmesi dolayısı ile bir şansın kaybının uygulanabilirliği sorunu zaten tartışılmıştır. Tıbbi sorumluluk, sözleşme veya haksız fiil sorumluluğu niteliğinde olabilir ${ }^{92}$.

Burada içtihatta ve modern doktrinde "bir șansın kaybı" kavramı ile hesaba katılan zarar kavramının "alt sınırı"na değiniyoruz. Bu durumda ümit edilen sonuç özellikle tesadüfi bir özelliğe sahiptir. Şu halde, onun

89847 fikra 1 cümle 2 BGB, 14.3.1990 tarihli yasayla (BGBl I s. 478) yürürlükten kaldırılmıştır. Kasche (s. 25), her ne kadar 1999 tarihli eserinde, Almanya'da manevi tazminata ilişkin taleplerin $\S 847 \mathrm{BGB}$ değişikliğinden sonra mümkün olduğunu belirtmiş ise de, daha sonra da maddenin tamamı yürürlükten kaldırılmıştır.

${ }^{90}$ OGH, 30.9.1996 6 Ob 2068 / 96 b JBl 1997, 40.

${ }^{91}$ Kasche, s. 25; OR I (- A.K. Schnyder)

${ }^{92}$ Müller, s. 353, N. 518. 
yokluğunun gerçekten bir zarar oluşturup oluşturmadığ 1 sorusu ortaya çıkmaktadır. Böylece bir doktor hastasına iyileşme şanslarını kaybettiriyor. Böyle bir varsayımda bir zarar kabul etmek gerekir mi, gerekmez mi? Sorun hala tartışmalıdır. Gerçekte bu sorunsallık, zararın kanıtlanması ile birleşmektedir. Kanıtlama, İsv. Borçlar Kanunu m. 42 / I'e göre davacıya düşmektedir. Zararın tam tutarı tespit edilemediği zaman İsv. BK.m. 42 / II, “.....yargıcın onu, olayların normal akışını ve mağdur tarafın aldığ 1 önlemleri dikkate alarak, adil bir biçimde belirleyeceğini söylemektedir. İçtihada göre, zararın mevcudiyetinin ispatına da uygulanan bu hüküm şu halde, İsv.BK.m. 42/ I 'deki kurala bir istisna oluşturmaktadır ${ }^{93}$.

\section{B.Sözleşme Sorumluluğu}

\section{Genel Bilgiler}

İsviçre'de ise, doktorla yapılan bu sözleşme vekâlet sözleşmesi ${ }^{94}$ olarak düzenlenmiştir. Sözleşme sorumluluğu, tıbbi sorumluluk olaylarının büyük çoğunluğunu gösteri ${ }^{95}$. Hasta ile doktor arasındaki özel uygulamadaki hukuki ilişkiler, devamlı bir kazai içtihat gereği, 394 CO ve devamı maddelerine göre, vekâlet olarak nitelendirilmişlerdir ${ }^{96}$. Sözleşmenin kesin veya zımni sonucuna göre, doktorun genel özen gösterme görevinden kaynaklanan çeşitli yükümlülükleri vardır: hastayı bilgilendirmek ve onun bilgili rızasını alma yükümlülüğü, belgelendirme yükümlülüğü ve hesap verme yükümlülüğg̈, vekaletin sahasını değerlendirme yükümlülüğü, bir teşhis verme yükümlülüğü, uygun bir tedavi yolu seçmek yükümlülüğü, bir uzmana danışmak yükümlülüğü veya tedaviyi reddetmek yükümlülüğü. Eğer doktorun başarılı olacak bir tedaviyi sağlamak için gerekli eğitimi veya malzemesi yok ise, ayrıca seçilmiş bir tedaviyi uygulamak yükümlülüğü, sürekli eğitim yükümlülüğü, ağzı sıkı olma ve sır saklama yükümlülüğü.

\footnotetext{
93 Guggenheim, Daniel : Le Droit Suisse des Contrats, Tome II, Les effets des contrats, Genéve 1995, s. 154.

94 Honsell, H. : Handbuch des Arztrechts (1994), s. 22-23; Ott, s.23; Kuhn, M. : Die Entwicklung in der Haftpflicht des Arztes, ZSR, N.F. 105, 1986, I. Halbband, s. 472-474; Loeffler, W. : Die Haftung des Arztes aus ärztlicher Behandlung, Zürich 1945; Schroeder, Karl : Probleme der zivilrechtlichen Haftung des freipraktizierenden Zahnarztes, Zürich 1982, s. 21; Nägeli, Max : Die äztliche Behandlung handlungsunfähiger Patienten aus zivilrechtlicher Sicht, Zürich 1984, s. 71; Merz, Barbara: Analyse der Haftpflichtsituation bei Schädigung durch Medikamente, Zürich 1980, s. 62; Frank, Richard : Persönlichkeitsschutz heute, Zürich 1983, s. 174; Stürner, Rolf: Die schweizerische Arzthaftung im internationalen Vergleich, SJZ 1984, (s. 121-130) s.122.

${ }^{95}$ Kuhn, Moritz : Die Arzthaftung in der Schweiz, 17 MedR (1999) , s. 248 vd. ; Müller, s. 354, N. 519.

${ }_{96}$ ATF 105 II 284 [284] , 53 II 419 [424] ; Payllier, Pascal : Rechtsprobleme der ärztlichen Aufklärung unter besonderer Berücksichtigung der spitalärztlichen Aufklärung, thése , Zürich 1999, s. 208; Kuhn, s.248; Müller, s. 354, N. 519.
} 
Sözleşme sorumluluğunun amacı, mağdur hastanın sözleșmenin ifa edilmemesi veya gereği gibi ifa edilmemesi dolayısı ile uğradığı zararın tazmin edilmesidir. Sözleşmenin gereği gibi ifa edilmemesi ise, özen gösterme görevinin ihlalidir (398 II ve 97/ I CO). Hasta, ilke olarak, uğradığı zararı kanıtlamalıdır, doktor tarafından sözleşmenin ihlali ve zarar veren etkinlikle uğranılan zarar arasındaki uygun nedensellik bağını da kanıtlamalıdır. Nedensellik kanıtı söz konusu olduğunda Federal Mahkemenin kazai içtihadı, yanlış bir tedavi veya yetersiz bir eğitim dolayısı ile ortaya çıkan durumlarda çeşitli gereksinimler ortaya koymaktadır. Doktorun kusuru, 97 / I ve 398/ I CO'ya göre varsayılmıştır ve pratisyen doktor (kuramsal olarak) sözleşmenin ihlâlinin kendisine yüklenemez oluğunu kanıtlayarak sorumluluktan kurtulabilir. Eğer hasta tarafından uğranılan zararın, doktorun kusurlu davranışından ileri geldiği açıkça anlaş1lıyorsa, mahkemeler ispat yükünü hafifletmeyi kabul etmişlerdir. Bu da res ipsa loqitur gereği karar veren İngiliz kuramını hatırlatır : Federal Mahkeme böylece doktorun özen gösterme görevinin ihlâlini bir ilacın vücuda enjekte edilmesi sonucu bir enfeksiyonun ortaya çıkması durumunda düşünülebileceğini kabul etmiştir ${ }^{97}$. 1987 yılından beri Federal Mahkeme, doktorların her türlü kusurlarından dolayı sorumlu olduklarını, hatta hafif kusurlarından bile sorumlu olduklarını düşünmektedir $^{98}$. İspat yükünün paylaşılması düzeyinde özel çözüm yolları, doktor tarafindan bilgi veme görevinin ihlâli ile ilgili olarak önceden anlatılmıştır ${ }^{99}$.

\section{Bir Şansin Kaybedilmesi}

Bu 17 Kasım 1988 tarihli Zürih kantonunun bir kararıdır ${ }^{100}$ ve İsviçre hukukunda iyileşme veya hayatta kalma şanslarının kaybının hangi şekilde tazmin edileceğini mükemmelen göstermektedir. Bunu açıkça söylemeseler de, Zürihli hâkimler Fransız, Amerikan, Belçikalı ve Hollandalı hâkimlerin kullandığı bir muhakeme biçimini uygulamışlardır ve tıbbi bir şansın kaybını tazmin etmişlerdir. İsviçreli hâkimlerin, sürekli maluliyet ile veya ölüm ile üstün olası nedensel bir ilişkinin gerekirliliğini muhakeme tarzlarında değişiklik yapmalarına ihtiyaçları olmayacaktır ve sonradan da 43/ I CO gereğince hatta doğru tedavinin durumunda gerçekleşcek olan nihai zararın meydana getireceği kalıcı riski de hesaba katmak durumunda kalmayacaklardır.Yeni bir zarar türü olarak bir şansın kaybının kabul edilmesi, doğrudan doktorun kusuru sonucu uygun nedensellik bağ1 ile hasta tarafından uğranılan şans kaybının arasındaki bağı doğrudan analiz etme imkânını verecektir ve şans kaybının önemine göre bir tazminata karar verilmesine imkân verecektir .

\footnotetext{
${ }^{97}$ ATF 120 II 248.

${ }^{98}$ ATF 113 II 429 [432 s.]

${ }^{99}$ Müller, s. 355, N. 519.

${ }^{100}$ Bkz. Müller, s. 179, N. 245 vd.
} 
Yabancı kazai içtihatın analizi, tıbbi konuda doğal nedensellik bağı üzerinde şüpheli durumların ne kadar çok ortaya çıktığını göstermektedir. Şu andaki ya hep ya hiç ilkesine uyan ve hâkimi çoğu kez bilemiyeceği şeyleri yeterli bir kesinlikle bilir görmeye zorlayan radikal çözüm kısmen uygulamaya müsait değildir. Tıbbi şansların tazmininini kabul etmenin benimsenmesi, İsviçre hukukunda da bundan böyle önemli hale gelmektedir ${ }^{101}$.

\section{Türlerin Sinıflandırılması}

Tıbbi şansların kaybına ilişkin türler insana etki yapacak kadar çeşitlidir. Aşağıda belirtilen olay kategorileri doktor tarafindan ihlal edilmiş yükümlülüklerin işlevi olarak oluşabilirler :

*Kötü bir tedavinin uygulanması (çoğu kez bir teşhis hatası), zira iyi bir tedavinin hastayı iyileştirceği hiçbir zaman bilinemez .

*Aslında doğru olan bir tedavinin uygulanmasındaki hata, zira iyi bir uygulamanın hastayı kurtarmaya yetip yetmeyeceği bilinemez.

*Tedavideki gecikme, zira zamanında uygulanmış olan tedavinin hastanın iyileşmesine veya hayatta kalmasına imkan verip vermiyeceği bilinemez.

*Hastanın rızasını alabilmek için eksik bilgi verilmesi veya hiç bilgi verilmemesi halinde, doktor gerekli dikkat ve özeni göstermemiş ve aydınlatma yükümlülüğünü de ihlal etmiş olur. Zira hasta bu müdaheleye eğer onun gerektirdiği riskleri bilse idi, rıza göstermekten vazgeçebilirdi ve sonunda gerçekleşmiş olan riskler bilinemez ${ }^{102}$.

Aynı olay türleri kamusal tıbbi sorumluluk konusunda da bulunur ${ }^{103}$.

\section{C.Haksız, Fiil Sorumluluğu}

\section{Genel Açıklama}

$41 \mathrm{CO}$ vd. maddesi gereği, haksız fiil oluşturan veya sözleşme dışı sorumluluk, doktorla hasta arasında bir sözleşme bir ilişkisi yoksa ortaya çıkar:Gerçekten, bir tedavi sonucu eğer bir hasta fiziksel veya ruhi bütünlüğünde bir yaralanmaya duçar olursa, bu onun vücut bütünlüğüne hukuka aykırı olarak verilen bir zarar olur, o halde bir haksız fiil oluşturur. $\mathrm{Bu}$ durumda, hasta olan şahıs, zararı, hukuka aykırlığı, doktorun davranışı ile uğranılan zarar arasındaki bağı kanıtlamalıdır.Vekilin (doktorun) kusuru, sözleşmeden doğan sorumluluğun aksine burada düşünülmüştür ve hasta

\footnotetext{
${ }^{101}$ Müller, s. 355, N. 520.

102 Müller, s. 355- 356, N. 521. Ayrıca bkz. Müller, s. 293-294, N. 433.

${ }^{103}$ Bkz. Müller, s. 356- 357, N. 524.
} 
olan şahıs, doktorun kusurlu olduğunu kanıtlamalıdır. Doktorla hasta arasında bir vekâlet sözleşmesi varsa ve doktor tedavisi çerçevesinde mutlak bir hakkı ihlal ediyorsa, örneğin vücut bütünlüğü gibi, mağdur olan hasta sözleşme yolu ile ve sözleşme dişı yol arasında uğranılmış olan zararın tazmin edilmesi konusundaki iddiasını seçmek durumundadır. $\mathrm{Bu}$ durumda, genellikle birinci yolu seçecektir, zira bu yol hastanın hakkını öne sürmesi $(55 \mathrm{CO}$ yerine $127 \mathrm{CO})$ ve tali sorumluluklar için de $(55 \mathrm{CO}$ yerine $101 \mathrm{CO}$ ) ve kuramsal olarak en azından kusurun kanitlanmasi yükümlülüğü bakımından daha müsaittir ${ }^{104}$.

\section{Bir şansin kaybedilmesi}

Sözleşmeden doğan sorumluluk çerçevesinde kayıp olan şansların tazmini konusunda yapılmış olan dikkat çekmeler, mutatis mutandis ilkesi gereği, hatta haksız fiil oluşturan veya sözleşme dişı sorumluluk konusunda da değer taşırlar. Gerçekten, zararın hesaplanmasını düzenleyen normlar ve tazminatın tespiti normları sözleşme sorumluluklarına, aynı zamanda haksız fiil sorumluluklarına da uygulanır ${ }^{105}$.

\section{D.Yasal Mevzuat}

İsviçre'de, bugünkü iç hukukta, şans kaybının tazmin edilmesini sağlayacak hiçbir hüküm yoktur ${ }^{106}$. Buna karşı1ık, İsviçre'nin de kabul ettiği

${ }^{104}$ Müller, s. 356, N. 522.

${ }^{105}$ Müller, s. 356, N. 523.

${ }^{106}$ Müller, Christoph : La perte d'une chance, Etude comparative en vue de son indemnisation en droit suisse, notamment dans la responsabilité médicale, Berne 2002, s. 177, N. 241. İsviçre'de sorumluluk hukukunun toptan revizyonuyla ilgili araştırma - inceleme komisyonunun raporuna dayanılarak, 1999 sonbaharında sorumlukuk hukukunun gözden geçirilmesi ve birleştirilmesi konusunda yeni bir federal yasa ön tasarısı ile açıklayıcı bir rapor sunulmuştur. Bu ön tasarının $56 \mathrm{~d}$ II maddesi (Article $56 \mathrm{~d}$ II AP LRCiv), şans kaybını da ilgilendirmektedir. Araştırma- inceleme komisyonunun tekliflerine göre ön tasarının yazarları, tam tutarı tespit edilemeyen zararın takdirini yöneten kuralın gelecekteki hukuka tekrar konulması gerektiği görüşündedirler (İsviçre Borçlar Kanunu'nun 42 / II maddesi). Fakat, onlar bugünkü içtihadın ilkelerinden ilham alarak yasanın gelecekte genel sözlerle ispat yükünün titizlikle paylaştırılmasını hafifletmeye yönelik maddibir karine vaz etmesini de teklif etmektedirler. Kanıt kesin, emin olarak tesis edilemediği veya onun kendisine düşen kişiden istenmesinin makul olmadığı durumlarda bu karine uygulama bulmalıdır. Böyle bir durumda, Madde 56 d II AP LRCiv mahkemeye "ikna edici bir olasıllk" ile yetinme olanağı verebilir. Bu hüküm ona aynı zamanda tazminatın kapsamını olasılık derecesine göre tespit etme yetksini de verebilir. Ön tasarının sistematiği konusunda Madde 56 d AP LRCiv'in sorumluluğun genel hükümlerini ihtiva eden birinci alt başlıkta bulunmasının tespit edilmesi ilginçtir. O, "İspat yükü ve maddi karine" derkenar başlığını taşımakta ve "kanıtlar"ın altındaki "Prosedür ve kanıtlar" bölümüne girmektedir. Madde 56 II AP LRCiv'in içeriği şöyledir: "1) Zarar ve illiyet ilişkisinin ispatı tazminat isteyen kişiye düşer. 2)Kanıt kesin, emin olunarak tesis edilemediği ya da onun getirilmesinin kendisine düşen kişiden istenmesinin makul olmaması durumunda, mahkeme ikna edici bir olasıllkla yetinebilecek; bundan başka tazminatın kapsamını olasılı̆̆ın derecesine göre tespit etmeye yetkili olacaktır. 3) Zararın tam doğru tutarı tesis edilemediği zaman, mahkeme şartları ve olayların olağan 
Uluslararası Ticaret Sözleşmesi ile İlgili Unidroit (Tek Hukuk) İlkelerinde (m. 7.4.3) şans kaybına ilişkin düzenleme bulunmaktadı1 ${ }^{107}$.

\section{E. İçtihad}

\section{Karar Bulunmaması}

Şimdiye kadar hiçbir kanton mahkemesi ya da federal mahkeme, şans kaybı teorisini özel surette uygulamamıştır. 1988'deki Zürih Yüksek Mahkemesi kararı, tek örnek olarak kalmaktadır, zaten mahkeme de bu kararda bir şansın kaybı teorisinden söz etmemektedir ${ }^{108}$.

Ancak, şansın kaybı nedeniyle tazminat talebi (Claim for loss of opportunity) ile ilgili bir hakem kararı bulunmaktadır. Milletlerarası Ticaret

akışını dikkate alarak onu adil bir biçimde takdir eder." (Müller, s. 186, N. 256). Bu yeni kural, farazi illiyet durumlarının ve özellikle de alternatif illiyet durumlarının ortaya çıkardığı sorulara tam cevaplar vermeye olanak tanıyacaktır (Rapport explicatif, s. 245; Müller, s. 187; N. 260). Ön tasarının yazarları, aynı zamanda şu görüştedirler: "Mahkemeye verilmiş olan tazminatın kapsamını olası görürlüğün derecesine göre tespit etme yetkisi, özel bir durumda, illiyetin tesis edilmesi mümkün olmaksızın söz konusu sorumluluğun temeli ile zararların sıklığı arasında istatistiki olarak tespit edilen bir sebep- sonuç ilişkisi mevcut olduğu zaman da kullanılabilir.(....) Aynı muhakeme, tıbbi sorumluluk olaylarında da yürütülebilir; örneğin, hasta rastlantısal bir ameliyat sonucu vefat ettiği zaman, oysa ki eğer doktor kusurlu bir biçimde dikkat ve özen ödevini ihmal etmemiş olsa idi, makul bir biçimde o hasta konusunda hayatta kalma şansları beklenebilirdi. Böyle bir olasılıkta, hiçbir şey yargıcın Fransız hukukunda ve İngiliz- Amerikan hukukunda özellikle geliştirdiği şekilde, zararın tazminini "bir şansın kaybolması" denilen ölçüte göre tespit edilmesine engel olamaz (Rapport explicatif, s. 245; Müller, s. 187, N. 260). Araştırma- inceleme komisyonunun ve ön tasarının yazarlarının İsviçre hukukuna bir şansın kaybolmasını sokmak istedikleri şeklin bir eleştirisi için bkz. Müller, s. 231, N. 325 vd.

${ }^{107} \mathrm{Bu}$ ilkelerde, 7. bölüm ("İfa etmeme”)'ün 4. kısmında ("Zarar - ziyan tazminatı), "Zararın kesinliğinden emin olma” adlı 7.4.3 maddesi şunu öngörmektedir : “(1) Zarar ancak makul bir kesinlik derecesi ile sabit ise, gelecekte bile olsa, tazmin edilebilir. (2) Bir şansın kaybolması, onun gerçekleşme olasılığı ölçüsünde tazmin edilebilir. (3) Tutarı yeterli bir kesin olma derecesi ile tespit edilemeyen zarar mahkemenin takdirine göre değerlendirilir." Şu halde bu madde, zararın kesinliğinin gerekli olduğunu teyid etmektedir, zira tamamen varsayımsal veya olası bir zararın tazmininin empoze edilmesi mümkün değildir.İstenilen kesin olma, bunun dişında, sadece haksızlığın mevcut oluşu ile değil, aynı zamanda onun kapsamı ile ilgilidir. Maddenin 2. fikrası, bir şansın kaybolmasının tazminine onun gerçekleşme olasılığı ölçüsünde özellikle olanak verir (Müller, s. 177-178, n. 242). İlkeler, özellikle tahkim bağlamında, uluslar arası özellikli tartışmalara uygulanabilen ulusal hukuku yorumlamak veya tamamlamak için giderek bir enstrüman olarak öne sürülmektedir. Bir şansın kaybı konusunda, bir hakemlik mahkemesi örneğin, bu zararın tazmini için Cezayir Medeni Kanunu bu anlamda hiçbir hüküm ihtiva etmemesine rağmen, madde 7.4.3 (2)'ye dayanmıştır. $\mathrm{Bu}$ davada hakemler, UNIDROIT ilkelerinin "dünyada ve uluslar arası sözleşmelerde hukuk sistemlerinde geniş ölçüde kabul gören kurallar benimsediklerini" açıklamışlardır. MÜLLER'e göre, İsviçre, UNIDROIT çerçevesindeki taahhüdüne uygun olarak, uluslararası ticaret konusunda diğer hukuk sistemleri ile bağdaşma nedenleri ile, bir şansın kaybının tazmin edilmesini kendi hukuk sistemine dahil etmekle kazançlı çıkacaktır (Müller, s. 178, N. 243).

${ }^{108}$ Müller, s. 178, N. 244. 
Odası'nın Uluslararası Hakemlik Mahkemesi'nin yayımlanmamıș bir hakem kararında ${ }^{109}$, İsviçreli bir hakem, bir şansın kaybı nedeniyle açılan bir davanın, bu davaya uygulanabilen İsviçre hukukuna göre, ilke olarak kabul edilebilir olduğuna karar vermiştir ${ }^{110}$.

\section{Zürih Yüksek Mahkemesi'nin 1988'deki Kararı}

$$
\text { a.Olaylar }{ }^{111}
$$

1971 Nisan ayında, bir hasta kanton hastanesinde (hâlen Üniversite hastanesi) sağ husyesinde bir tümör şüphesi ile muayene edilmişti. Hastayı ameliyat eden iki asistan doktor ve bir baş hekim, şüpheli hiçbir şey bulamamışlardı. Haziran ve Temmuzda yapılan daha sonraki kontrol muayeneleri sırasında husyede (testikülde) bir kalınlaşma gözlemlenmişti. Doktorlar bu kalınlaşmayı bir tümöre değil de, ameliyat sonucu olan bir kanamaya atfetmişlerdi. Bu nedenle doktorlar, endişe içinde bulunan hastanın yeni bir ameliyat yapılması yönünde gitgide artan ısrarına rağmen, yeni bir ameliyat gerçekleştirmekten vazgeçmişlerdi. Hastane müdürünün müdahalesi sonucunda husye nihayet 3 Eylül 1971 tarihinde ikinci bir defa ameliyat edilmişti. $\mathrm{Bu}$ ameliyat sırasında onun kesilip çıkartılması gerekti, zira daha şimdiden tümör onu ciddi bir biçimde sarmıştı. 6 Ekim'de doktorlar, metastazlara uğramış olan ilyak çukurunun lenf damarlarını kesip çıkartmak zorunda kalmışlardı. 1972 başında radyoterapi başlatılmıştı. Hasta 19 Ekim 1972'de kanser sonucu vefat etmişti ${ }^{112}$.

${ }^{109}$ CCI N. 8795 / BGD.

${ }^{110}$ Müller, s. 181, N. 248. Hakem bu sonuca, bu sorun ile ilgili doktrini ve içtihadı tahlil ettikten sonra ulaşmıştır. Özellikle de, İsviçre hukukunun davacının aktiflerinin her türlü istek dışı azalmasını sözleşmenin ifa edilmemesi halinde tazmin edilmesi gereken kayıplarda göz önüne alındığını gözlemlemiştir. Kâr kaybı, tıpkı sözleşmenin yerine getirilmemesinden mağdur olan kişinin hiç kuşkusuz üçüncü bir kişiye ödemek zorunda olduğu sözleşmesel gecikme cezası gibi, onun bir parçasını oluşturur. Hakem aynı zamanda, şartlı alacakların veya (varlığı şimdiki zaman içinde kesin olmayan) gelecekteki malların satış sözleşmelerine konu olabildiklerini ortaya koymuştur. Basit bir beklenti bile (örneğin bir piyangoda kazanma beklentisi) geçerli olacak bir biçimde satılabilir. O, böylesi beklentiler (kelimenin hukuki olmayan anlamı ile) satış sözleşmelerine konu olabilirlerse de, bunların aktifler olarak kabul edilmeleri gerektiği sonucuna varmıştır. Şu halde, bunlardan mahrum kalınması, tazmin edilmesi gereken bir kayıp oluşturur. Hakeme göre, bir şans kaybının tazmini için açılan davalar, iki koşula tabidirler : Bir yandan, sözleşmedeki bir yükümlülüğün ihlâli (genellikle bir özen gösterme yükümü), diğer yandan, șansın maddi hale geleceğinin olası olması. Hakem, bu sonuncu koşul konusunda, çok büyük bir olasılığın istenmediği görüşündedir, zira olasılık daha küçükse de, şansın maddi hale gelmesinin kesin olmayış derecesi, şansın kaybı için tahsis edilen tazminatın tutarına yansır. İște hakem buna dayanarak, 4,5 milyon ABD doları değerinde olabilecek bir sözleşme yapmak için \% 20 oranında bir şans kaybını tazmin etmek üzere, davalıyı diğer meblağlar arasında 900.000 ABD doları tutarındaki bir meblağı davacıya ödemeye mahkum etmiştir (Müller, s. 181, N. 248).

11187 ZR (1988) N.66 s. 209 vd., 85 RSJ (1989) s. 119 vd.

${ }^{112}$ Müller, s. 179, N. 245. 


\section{b. Hukuk}

Hastanın karısı ve çocukları tarafından kendisine hukuki bir sorumluluk davası ile başvurulan bucak mahkemesi, önce Zürih kantonunun sorumluluğunu reddetmişti. İtiraz üzerine Yüksek Mahkeme, önce, kanser teşhisinde gecikmenin, bu davanın koşullarında doktorların dikkat ve özeni gösterme yükümlülüklerinin ihlâlini oluşturduğunu kabul etmişti. Daha sonra mahkeme, bu ihlâller ile hastanın yakınlarının maruz kaldığı zarar arasındaki doğal illiyet bağı konusunda tartışmıştı (hastanın ölümü sonucu meydana gelen manevi zarar ve destek kaybı). Mahkemeye göre, hakkaniyete uygun karar verilebilmesi için davalıların özensizliği (ihmali) ile ortaya çıkan zarar arasındaki illiyet bağının ispatının güç olması dolayısıyla, davacıların kesin ispat yükünün hafifletilmesi gereklidir. Böylece mahkeme, basit bir illiyet bağ 1 olasılı̆̆ının ciddi bir biçimde mevcut olduğu delili ile yetinmişti.Yüksek Mahkeme, uygun olmayan tedavinin hastanın ölümü ile ağırlıklı bir olasılıkla illiyet bağı içinde bulunmasının Ağustos 1971 tarihinde (yarı kısırlaştırılmanın yapılması gerektiği zaman) veya 1971 Ağustos ayı ortasında (lenf damarlarının alınması gerektiği zaman) mevcut bulunan hayatta kalma şanslarına bağlı olduğuna hükmetmişti. Yüksek Mahkeme, bu mantık yürütme şeklinin, hayatta kalma şanslarının \% 60 veya daha fazla olması durumunda kendisine kabul edilebilir gibi göründüğünü, zira o zaman ihmalin ağırlıklı bir olasılıkla ("mit überwiegender Wahrscheinlichkeit") zararın nedeni olduğunu belirtmişti. Eğer kanser zamanında teşhis edilmiş olsa idi, hayatta kalma şansının yaklaşık \% 60 olacağını varsayarak, mahkeme, bunun illiyet bağını tesis etmeye yeterli olduğuna karar vermişti. Fakat erken teşhis ve özenli tedavi halinde bile, hastanın belki de vefat edebileceği şeklindeki \% 40 riskin, İsviçre Borçlar Kanunu'nun 43 / I maddesi gereğince, tazminatın saptanmasında göz önüne alınması gerektiğini düşünmüştü ${ }^{113}$.

\section{c. Yorumlar}

GUILLOD, bir şansın kaybı teorisinin bu karar ile İsviçre hukukunda ortaya çıktığını düşünmektedir ve Zürihli yargıçların bu kararı ağırlıklı Amerikan içtihadını örnek alarak, fakat onu zararın hesaplanmasında dikkate alan Fransız içtihadına ters olarak, illiyet alanına soktuklarını belirtmektedir" ${ }^{114}$. Bundan başka, Yüksek Mahkeme'nin "şanslar zayıf gözüktüğü takdirde (\% 50'den az), teorinin uygulanmasını reddeder gibi göründüğü” gözlemini yapmaktadır ${ }^{115}$. Bu yazar, aynı zamanda Yüksek Mahkeme'nin ispat yükünün hafifletilmesini kabul ederek, illiyet konusunda

\footnotetext{
${ }_{113}^{11}$ Müller, s. 179, N. 246.

${ }^{114}$ Guillod, Oliver : La responsabilité civile des médecins : un movument de pendule, in : M. Borghi / O. Guillod / H. Schutz (éd.), la responsabilita del medico e del personale sabitario fondata sul diritto publicco, civile e penale, Lugano 1989, s. 78; Müller, s. 179- 180, s. 247.

${ }^{115}$ Guillod, s. 79.
} 
bir tezada düşmekten dâhiyane bir şekilde kaçtığını belirtmektedir ${ }^{116}$. STARK, davalının kusuru nedeniyle ispatlama imkânsızlığı konusunda doktrine başvurulmasının bu davada belki de kabul edilebilir olduğu, fakat sorumluluk hukuku açısından tatmin etmediği görüşündedir. Yazar, soruna toplu bir bakışın hayatta kalma şanslarını imkânsızlaştıran şeyin doktorların kusuru mu yoksa başka koşulların mı olduğu sorusunun cevabının sonuçta tesadüfe bağlı olduğunu ortaya çıkardığını düşünmektedir. Ona göre, Zürih Yüksek Mahkemesi hastanın basit hayatta kalma olasılığı yüzünden yeterince dikkat göstermeyen doktorların sorumluluğunun bulunmadığını kabul etmek istememiştir. Tam sorumluluk bulunduğunun kabul edilmesi, hastanın yakınları için tatmin edici olacaktı. Fakat bu kabul, davanın nihai sonucu için bu davada tesadüfe bağlı olan ve çoğu zaman benzer davalarda işin içinde bulunmayan doktorların kusuru ile ispatlamanın imkânsızlığına fazlaca büyük, sonuç üzerinde kesin etkisi olan bir yer ayırmaktadır ${ }^{117}$. İşte bu nedenle o, İsviçre hukukunda bir şansın kaybolması konusunda Fransız içtihadının benimsenmesinin Zürih mahkemesinin bulduğu çözümden daha âdil bir çözüm oluşturabileceği görüşündedir ${ }^{118}$. HONSELL, illiyet sorunu için Yüksek Mahkeme'nin yaptığ 1 ispat yükünün tersine çevrilmesinin yasada bir dayanağı olmadığı gözlemini yaparak, bu içtihadı eleştirmektedir. İsviçre Borçlar Kanunu'nun 97 / I maddesine göre kanıtlayıcı bir gerekçe kanıtının bir görevin ihlali sorununa, hele de illiyet sorununa değil, sadece kusur sorununa uygulandığını düşünmektedir ${ }^{119}$. WEBER, ispat yükünün tersine çevrilmesinin sorunlu olduğu görüşündedir. $O$, eğer mahkeme hastaya gerçekten yardım etmek istiyorsa, kesin, net delil istemek yerine olasılıklı bir kanıt ile yetinerek, ispat yükünü hastaya yükletmesi gerektiğini düşünmektedir ${ }^{120}$. KOZIOL, Yüksek Mahkeme'nin kararının temelindeki olayların bir şansın kaybolması teorisinin 1şığında tahlil edilemeyeceği, zira, bu davada bağımsız bir mal değeri olan bir șansın kaybının söz konusu olmadığ1 görüşündedir ${ }^{121}$. GÜNTER'e göre, “illiyet sorununu inceledikten sonra (\% 60 hayatta kalma şans1), ölüm riskinin (in casu \% 40) hesaba katılmasının tazminatın tespiti sırasında İsviçre Borçlar Kanunu'nun 43. maddesine göre düşünülmesi gerektiğini kabul ettiği zaman" Yüksek

\footnotetext{
${ }^{116}$ Guillod, s. 79.

${ }^{117}$ Stark, Emil Wilhelm : Die "perte d'une chance" im schweizerischen Recht, in : O.Guillod (éd. ), Développements récents du droit de la responsabilité civile, Zürich 1991, (s. $101 \mathrm{vd}$.) s. 108; Müller, s. 180, N. 247.

${ }^{121}$ Koziol, Helmut : Der Beweis der natürlichen Kausalität, in : A. Koller (éd.), Haftpflicht und Versicherungsrechtstagung 1999, St. Gallen 1999, (s. 79 vd. ), s. 99; Müller, s. 180, N. 247.
} 
Mahkeme'nin kararı izlenmeye değer olacaktır ${ }^{122}$. LOSER, Yüksek Mahkeme'nin \% 50 veya daha fazla bir olasılık şartını devam ettirdiğini söyleyerek, bu kararın önemini izafileştirir. O, bir şansın kaybolması davalarının özel durumlar oluşturduğu görüşündedir ve bu kararı daha ziyade, İsviçre Borçlar Kanunu'nun 43. maddesine göre, kesin olmayan bir illiyet ilişkisinin telafisi olarak, tazminatın azaltılmasının doğmatik temeli gibi görür ${ }^{123}$. QUENDOZ, bu davanın Fransız hukukunda bir şansın kaybolmasının uygulanması olayı gibi kabul edilebileceğini düşünmektedir. Bununla birlikte, kesin olmayışı sorumluluk doğuran (haftungsbegründend) illiyeti değil, tazmin olunacak zarara ilişkin (haftungsausfüllend) illiyeti kapsadığını vurgular ${ }^{124}$. Alman yazar KASCHE, bu kararın Alman geleneğine sahip mahkemelerin nasıl sonuçlarında da iyileşme şansının kaybının tazmin edilmesine olanak veren çözümler bulduklarını açıkladığı görüşündedir ${ }^{125}$.

MÜLLER'e göre, Zürih Yüksek Mahkemesi'nin, tıbbi hatanın yapıldığı sırada, sadece \% 60 oranında hayatta kalma şansı olan bir hasta için tazminatı İsviçre Borçlar Kanunu'nun 43 / I maddesi gereğince \% 40 oranında azaltan 1988 tarihli kararı, şans kaybı teorisini de özellikle zikretmemekte olup, bu tarihten önce ve sonra bu konuda benzeri mahkeme kararına rastlanmamaktadır ${ }^{126}$. Ancak bir hakem, 1988'deki bir kararla, İsviçre hukukunun, bir şansın kaybını tazmin etmeye olanak verdiğini düşünmüştür ${ }^{127}$.

Zürih Yüksek Mahkemesi'nin kararını bir de biz değerlendirmek istiyoruz. Olayda, önce doktorların kanser teşhisinde gecikmeleri nedeniyle, dikkat ve özen gösterme yükümlülüklerini ihlâl etmeleri dolayısıyla, önce iyileşme şansının kaybı ve bunun neticesinde hastanın ölmesiyle, insanın en değerli varlığ Mahkeme, kanserin zamanında teşhis edilmesi halinde, hayatta kalma şansının yaklaşık \% 60 olacağını varsayarak bunun illiyet bağını tesis etmeye yeterli olduğuna karar vermiştir. Burada, GUILLOD'un da ifade ettiği gibi, mahkemenin şans kaybını bir zarar teorisi olmaktan çok, bir illiyet teorisi olarak ele alması eleştirilebilir. Ayrıca, yazarın dediği gibi, Yüksek Mahkemenin bu kararından şansların zayıf gözükmesi, diğer bir ifadeyle, \% 50'den az olması halinde, şans kaybı teorisinin uygulanmasını reddeder gibi göründüğü izlenimini çıkarmak da mümkündür. Olayda, ölenin

${ }^{122}$ Günter, Pierre- Yves : La responsabilité civile des médecin en Suisse, 89 RSJ (1993), (s. 93 vd.), s. 97; Müller, s. 180, N. 247.

${ }^{123}$ Loser, Peter : Kausalitätsprobleme bei der Haftung für Umweltschäden, thése, Bern / Stuttgart / Wien 1994, s. 228; Müller, s. 180, N. 247.

${ }^{124}$ Quendoz, Roger : Modell einer Haftung bei alternativer Kausalität, thése, Zürich 1991, s. 71 ,dn. 213, Müller, s. 180-181, N. 247.

${ }^{125}$ Kasche, s. 173.

${ }^{126}$ Müller, s. 182, N. 249.

${ }^{127}$ Müller, s. 182, N. 249. 
çocukları ve eşi bu şekilde baba ve eşin yaşama şansını kaybetmesi nedeniyle destekten yoksun kalmışlardır. $\mathrm{Bu}$ nedenle, yukarıdaki açıklamamız saklı kalmak kaydıyla, ölenin ailesinin destekten yoksun kalma tazminatı ve manevi tazminat taleplerinin Zürih Yüksek Mahkemesince kabulüne karar verilmesi kanaatimizce isabetli olmuştur. Zira, tıbbi sorumluluk alanında da, şans kaybı nedeniyle uğranılan zararın tazmin edilmesi adalet duygularına uygun düşmektedir.

\section{V.Türk Hukukundaki Durum}

\section{A.Doktorun sorumluluğu bakımından Türk hukuku}

\section{Doktorun Hukuki Sorumluluğunun Türleri}

a.Kusur Sorumluluğu

Doktorun hukuki sorumluluğu alanında diğer sorumluluk türlerini esas alan özel bir düzenleme mevcut olmadiğı için tıbbi faaliyetlerden doğan sorumluluk kural olarak kusur sorumluluğuna dayanır ${ }^{128}$. Doktor ile hasta arasinda daha önceden kurulmuş geçerli bir sözleşmenin bulunması halinde, doktorun hukuki sorumluluğu hakkında Borçlar Kanunu'nun 96. ve sonraki maddeleri, bu tür sözleşmesel bir ilişkinin bulunmaması halinde ise, Borçlar Kanunu'nun haksı fiile ilişkin 41. ve sonraki maddeleri uygulama alanı bulur. Bu maddelere göre sorumluluğun kurucu unsuru kusur olduğundan, doktor tıbbi faaliyetleri sonucu meydana gelen zarardan ancak kusurlu olduğu takdirde sorumlu olur, kusuru bulunmadiğl takdirde sorumlu tutulamaz ${ }^{129}$.

\section{b. Sebep Sorumluluğu}

Olağan sebep sorumluluğu, doktorun hukuki sorumluluğunda, bu sorumluluk türünün tipik birer örneği olan, Borçlar Kanunu'nun 55. ve 58. maddeleri dolayısıyla söz konusu olmaktadır. Doktor tıbbi faaaliyetleri esnasında yardımcı şahıs kullandığında, kendisi ile sözleşme ilişkisi içinde bulunmayan hastalara, bu yardımcı şahısların vermiş olduğu zararlardan BK.m.55'e göre sorumlu tutulmaktadır ${ }^{130}$. Bu faaliyetler sırasında kullanılan, belirli niteliklere sahip tıbbi alet ve makinelerdeki yapım ve bakım

\footnotetext{
${ }^{128}$ Şenocak, s. 6. Bu konuda ayrıca bkz. Belgesay, s. 85; Reisoğlu, s. 3; Aşçıŏglu, s. 72; Kaneti, S. : Hekimin Hukuksal Sorumluluğunda Kusurun ve İspat Yükünün Yeri, Türk Hukukunda Hekimin Hukukî ve Cezai Sorumluluğu, Sorumluluk Hukukundaki Gelişmeler V. Sempozyumu, Ankara 12- 13 Mart 1982, İstanbul 1983, s. 62; Ertaş, s. 175.

${ }_{129}$ Senocak, s. 6.

130 Şenocak, s. 7. Bu konuda ayrıca bkz. Aşçıŏ̆lu, s. 105; Belgesay, s. 139; Reisoğlu, s. 15.
} 
eksikliklerinin bir zarara neden olması durumunda da BK.m.58 gereğince sorumluluğu ortaya çıkmaktadır ${ }^{131}$.

Tıbbi sorumluluk alanında tehlike sorumluluğunu esas alan özel bir düzenleme olmadığı için bu sorumluluk türü doktorun hukuki sorumluluğunda uygulama alanı bulamamaktadır. Ancak tıbbi faaliyetler esnasında doktorların küçücük bir hatasının insan sağlığı ve yaşamı için son derece önemli, telafisi imkânsız zararlara yol açması, bu alanda da tehlike sorumluluğu esasına yer verilmesi gerektiğini ileri süren görüşlerin ortaya çıkmasına neden olmuştur ${ }^{132}$.

\section{Doktorların Hukuki Sorumluluğunun Sebepleri}

\section{a.Doktorun Sözleşmesel Sorumluluğu}

\section{aa.Genel Olarak}

Eğer doktor ile hasta açık veya örtülü olarak bir sözleşme ilişkisi içine girmişlerse, doktorun hukuki sorumluluğunun kaynağını bu sözleşme oluşturur. Doktorların sorumluluğu bakımından sözleşmesel sorumluluk, bir sözleşmeyle taahhüt altına girmiş olan doktorun, bu sözleşmeden doğan yükümlülüklerini ihlâl etmesi (hiç veya gereği gibi ifa etmemesi) sonucunda sözleşmenin karşı tarafi olan hastaya vermiş olduğu zararı tazmin yükümlülüğünü ifade $\operatorname{eder}^{133}$. Söz konusu tazmin yükümlülüğünün doğabilmesi için aşağıda belirtilen şartların varlığı gerekir.

\section{bb. Doktorun Sözleşmesel Sorumluluğunun Şartlart}

\section{aaa.Sözleşme}

Doktorun sözleşmesel sorumluluğunun söz konusu olabilmesi için her şeyden önce doktorla hasta arasında önceden açık veya örtülü olarak kurulmuş bir tedavi sözleşmesinin varlığ gerekir $^{134}$. Türk hukukunda da hâkim görüsş, İsviçre'de olduğu gibi, bu sözleşmenin bir vekâlet sözleşmesi olduğunu kabul etmektedir ${ }^{135}$.

${ }^{131}$ Şenocak, s. 7.

132 Şenocak, s. 8.

133 Şenocak, s. 9. Bu konuda bkz. Tandoğan, Türk Mesuliyet...., s. 414; Eren, Borçlar Genel, C. II, s.21; Karahasan, s. 59.

${ }^{134}$ Şenocak, s. 9. Doktorla hasta arasındaki bu sözleşmenin hukuki niteliği konusunda gerek yabanc1 gerekse Türk doktrininde bir çok görüşler ileri sürülmüştür. Bu görüşlere daha sonra değinilecektir.

${ }^{135}$ Şenocak, Zarife : Özel Hukukta Hekimin Sorumluğu, Ankara 1998, s. 18; Reisoğlu, Seza : Hekimlerin Hukuki Sorumluluğu, Türk Hukukunda Hekimin Hukuki ve Cezai Sorumluluğu, Sorumluluk Hukukundaki Gelişmeler V. Sempozyumu, Ankara 12/ 13 Mart 1982, İstanbul 1983, (s. 1vd.) s. 12; Köprülü, Ömer : Hekimin Hukuki Sorumluluğu, İst. Bar. Der., 1984, C. LVIII, S. 10-11, s. 600; Belgesay, M.Reşit : Tıbbi Mesuliyet, İstanbul 1953, s. 16; Aşçıoğlu, Çetin : Tıbbî Yardım ve El Atmalardan Doğan Sorumluluklar, Doktorların Devletin ve Özel Hastanelerin Sorumluluğu (Cezai ve Hukukî), Ankara 1993, s.20; Tandoğan, Halûk : Borçlar 


\section{bbb.Sözleşmenin İhlâli}

Doktorun sözleşmesel sorumluluğunun ortaya çıkabilmesi için doktorla hasta arasında mevcut olan sözleşmenin doktor tarafından ihlâli, yani BK.m.96'ya göre "borcun hiç ya da gereği gibi ifa edilmemesi" gerekir. Doktor, hasta ile arasındaki sözleşmeyle genellikle hastalığ hastalığı iyileştirmek veya hastanın acısını hafifletmek için elinden geleni yapmayı taahhüt eder. Doktorun olumlu ya da olumsuz bir davranışla bu taahhütlere aykırı hareket etmesi sözleşmeye aykırılık oluşturur. Sözleşmesel sorumluluk için gerekli olan bu şart, haksız fiillerde söz konusu olan hukuka aykırılık şartının yerini tutar ${ }^{136}$.

\section{ccc.Zarar}

Zarar doktorun sorumluluğunun, dolayısıyla tazminat borcunun en önemli şartını oluşturur. Zararın bulunmadığı yerde tazmin yükümlülüğünden söz edilemez. Tibbi sorumlulukta maddi zarar, yükümlülüğe uygun bir tedavi yapılsaydı hastanın kavuşacağı sağlık durumu ile yürütülebilen hatalı tedavinin gerçek sonuçları arasındaki parayla ölçülebilen fark1 ${ }^{137}$, manevi zarar ise hatalı bir tedavinin sonucu olarak

Hukuku, Özel Borç İlişkileri [C. II İstisna (Eser) ve Vekâlet Sözleşmeleri, Vekâletsiz İş Görme, Kefalet ve Garanti Sözleşmeleri], 3. Bası, Ankara 1987, s. 360; Zevkliler, Aydın : Zevkliler Borçlar Hukuku, Özel Borç İlişkileri, 8.Bası, Ankara 2004, s. 375; Bilge, Necip : Borçlar Hukuku (Özel Borç Münasebetleri), Ankara 1971, s. 285; Ayan, Mehmet : Tibbî Müdahalelerden Doğan Hukuki Sorumluluk, Ankara 1991, s.53; Donay, Süheyl : Doktorun Hukuki Sorumluluğu, İktisadi ve Ticari İlimler Dergisi, S.10, 1968 (s.39-53) s.46; Olgaç, Senai : İstisna Akdi, Ankara 1977, s. 5-6; Sarıal, Enis : Sağlararası Organ Nakillerinden Doğan Hukuksal İlişkiler, İstanbul 1986, s.41; Özdemir, Hayrünnisa : Özel Hukukta Teşhis ve Tedavi Sözleşmesi, Ankara 2004, s.81; Öztürkler, Cemal : Hukuk Uygulamasında Tıbbi Sorumluluk, Teşhis, Tedavi ve Tıbbi Müdahaleden Doğan Tazminat Davaları, Ankara 2003, s. 56-57.

Yargıtay da doktor hasta ilişkisinin vekâlet sözleşmesinin tüm unsurlarını taşıdığını ilke olarak benimsemiştir (Öztürkler, s. 57). Buna örnek olarak şu karar verilebilir: "Özet : Hasta ile doktorun meslek ilişkisi vekillik sözleşmesine dayanır. Vekil, iş görürken yöneldiği sonucun elde edilememesinden değil, bu sonuca ulaşmak için yaptığı uğraşların özenle görülmemesinden sorumludur. Vekilin sorumluluğu, genel olarak işçinin sorumluluğuna ilişkin kurallara bağlıdır. Vekil, işçi gibi özenle davranmak zorunda olup hafif kusurundan bile sorumludur. O nedenle doktorun meslek alanı içinde olan bütün kusurlar (hafif de olsa) sorumluluğun unsuru olarak kabul edilmelidir.Doktorun sorumluluğunu tayin ederken hâkim, olayların özelliklerine uymayan, dayanakları gösterilmeyen inandırıcı olmaktan uzak bulunan Yüksek Sağlık Şurası raporu ile bağlı değildir. Bu rapor, Hukuk mahkemesini değil, ceza mahkemesini bağlar.

Belirtilen kurallara aykırı davranan vekil maddi ve manevi tazminatla sorumlu tutulmalıdır. Mesleki bir iş gören doktor olan vekilden ona güvenen müvekkil titiz bir ihtimam ve dikkat göstermesini beklemekte haklıdır. Titiz bir özen göstermeyen vekil, vakâleti gereği gibi ifa etmemiş sayılmalıdır" (Y.13.HD. E. 94 / 8557 , K. 2138 - YKD, S. 8, Ağustos 1994, s. 1288 )

136 Senocak, s. 10.

${ }^{137}$ Bkz. Ott, s. 83; Reisoğlu, s. 10 
hastanın duyduğu bedensel ve manevi acıyı, hayat zevklerinde meydana gelen azalmayı ifade eder ${ }^{138}$.

\section{ddd.Kusur}

Doktoru BK.m.96'ya göre sorumlu tutabilmek için gerekli olan bir diğer şart $\mathrm{da}$, doktorun tedavi sözleşmesinin kendisine yüklediği yükümlülükleri kasten veya ihmal ile ihlâl etmiş olmasıdır. Yani doktor zarara, hukuk düzeninin kınadığı, tasvip etmediği kusurlu bir davranışla sebebiyet vermelidir. Borçlar Kanunu'nun 96. maddesi sözleşmesel sorumluluk için kusur karinesine yer vermiştir. Yani bu maddeye göre borcunu hiç veya gereği gibi yerine getirmeyen borçlunun kusurlu olduğu kabul edilir ${ }^{139}$. Kusurlu olmadığını ispat borçluya düşer.

eee. Illliyet Bă̆

Doktor ancak kusurlu tıbbi faaliyetinin uygun sonucu olan zararlardan sorumludur. Eğer doktorun kusurlu davranışı zararın uygun sebebi olarak nitelendirilemiyorsa, yani doktorun kusurlu davranışı ile hastaya verilen zarar arasında uygun illiyet bağı yoksa, doktor açısından bir tazmin yükümlülüğü doğmaz ${ }^{140}$. Uygun illiyet bağının varlığının ispatı zarar görene düşer ${ }^{141}$.

\section{b.Doktorun Sözleşme Dışı Sorumluluğu}

\section{aa.Genel Olarak}

Doktorla hasta arasında daha önceden açık veya örtülü olarak kurulmuş bir sözleşme bulunmadığı takdirde, sorumluluğun kaynağını kural olarak ${ }^{142}$ bir haksız fiil (geniş anlamda bir haksız fiil) oluşturur. Böylece sorumluluk ya BK.m.41 gereğince haksız fiilden (dar anlamda haksız fiilden) veya sebep sorumluluğu (geniş anlamda haksız fiil) halleri olan BK.m.55 gereğince yardımcı şahısların fiilinden veyahut da BK.m.58 gereğince maliki bulunulan şeylerdeki (belirli nitelikteki tıbbi alet ve makinelerdeki) yapım ve bakım eksikliklerinden doğar ${ }^{143}$.

${ }^{138}$ Ott, s. 99; Reisoğlu, s. 10; Şenocak, s. 10.

139 Şenocak, s. 11. Tıbbi ve hukuki açıdan büyük önem taşıyan, meslek kurallarına aykırılık halinde ortaya çıkan meslek hatası veya meslek kusuru (Kunstfehler) hakkında ayrıntılı bilgi için bkz. Şenocak, s. 83- 84; Özdemir, s.162-169; Ayan, s.104-109.

${ }^{140}$ Şenocak, s. 11; Tandoğan, Türk Mesuliyet...., s. 77; Eren, Fikret : Sorumluluk Hukuku Açısından Uygun İlliyet Bağı Teorisi, Ankara 1975, s. 21 vd. Uygulamada ve doktrinde kabul edilen görüşe göre, tıbbi faaliyetlerden doğan hukuki sorumlulukta illiyet bağının ispatı çok zor olduğundan bu konuda çok sıkı davranılmamalı, zararın söz konusu fiilin sonucu olduğu büyük ihtimalle sabit olmuşsa, bu yeterli sayılmalıdır. Bkz. Reisoğlu, s. 9; Ott, s. 107. ${ }^{141}$ Şenocak, s. 11.

142 Doktorla hasta arasında daha önceden kurulmuş bir sözleşmenin bulunmadığ durumlarda (ameliyatın genişletilmesi, acil vakalar vs.), doktorun tıbbi müdahalesi vekâletsiz iş görme teşkil edebilir. Bu takdirde sorumluluk haksız fiilden değil, vekâletsiz iş görmeden doğar.

${ }^{143}$ Şenocak, s. 11- 12, s.12'de dn. 34. 


\section{bb.Doktorun Sözleşme Dışı Sorumluluğunun Şartları}

aaa.Fiil

Doktorun haksız fiilden doğan sorumluluğunun söz konusu olabilmesi için her şeyden önce doktor olumlu ya da olumsuz bir davranışta bulunmalıdır ${ }^{144}$. Doktorun olumlu davranışına örnek olarak, doktorun koma halinde bulunan hastaya deney maksadiyla müdahale etmesi verilebilir.Doktorun olumsuz davranışına ise, onun tıp mesleğinin kendisini yükümlü kıldığı acil olaylarda ilk yardım görevinden kaçınması örnek gösterilebilir ${ }^{145}$.

\section{bbb.Hukuka Aykırılık}

Hukuka aykırılık "kişilerin mal ve şahıs varlıklarını doğrudan doğruya koruyan emredici bir hareket tarzı kuralına aykırılık"tır ${ }^{146}$. Kural olarak üçüncü kişilerin şahıs varlıklarına yapılacak her müdahale hukuka aykırı ${ }^{147}$ olup, müdahale eden kişinin doktor olması durumu değiştirmez. Böyle bir müdahalenin hukuka aykırı sayılmaması için haklı bir sebebin varlı̆̆ gerekir.Tıbbi müdahalelerde bu haklı sebepler; hastanın rizasının bulunmas ${ }^{148}$, hastanın menfaatine uygun hareket etme ve hukuka uygun bir kamu gücünün kullanılmasıdır ${ }^{149}$.

ccc.Zarar

Tıbbi müdahalenin haksız fiil oluşturabilmesi için gerekli olan diğer bir şart da maddi veya manevi bir zararın varlığıdır. Sözleşmesel sorumluluk

\footnotetext{
144 Şenocak, s. 12. Doktorun Borçlar Kanunu'nun 55. maddesine göre sorumluluğunun doğabilmesi için, çalıştırılan yardımcı şahısların zarara sebebiyet veren olumlu veya olumsuz davranışlarının söz konusu olması gerekir. Doktorun BK.m. 58'den doğan sorumluluğunda ise zarara sebep olan bir insan davranışı değil, maliki bulunulan şeydeki yapım ve bakım eksikliğidir. Bu eksikliğin umulmayan bir halden veya üçüncü bir şahsın davranışından ileri gelemesi de durumu değiştirmez. Ancak, zarar eserdeki eksiklikten değil de malik veya üçüncü bir şahsın davranışından ileri gelmişse, eksiklikle zarar arasında uygun illiyet bağı bulunmadığı için BK.m. 58 uygulanmaz. Bkz. Tandoğan, Kusura Dayanmayan...., s. 174 vd.; Eren, Borçlar Genel, C. II, s. 214; Tekinay / Akman / Burcuoğlu / Altop, s. 519.

${ }^{145}$ Şenocak, s. 12.

${ }^{146}$ Bkz. Tandoğan, Türk Mes'uliyet...., s. 18; Eren, Borçlar Genel, C. II, s. 132; Tunçomă̆, s. 430; Honsell / Vogt / Wiegand, Art. 41, N. 31, 33.

147 Öztan, Bilge : Şahsın Hukuku, 6. Bası, Ankara 1994, s. 119; Reisoğlu, s. 4; Özsunay, Ergun : Alman ve Türk Hukuklarında Hekimin Hastayı Aydınlatma Ödevi ve İstisnaları, Türk Hukukunda Hekimin Hukukî ve Cezaî Sorumluluğu, Sorumluluk Hukukundaki Gelişmeler V. Sempozyumu, Ankara, 12- 13 Mart 1982, İstanbul 1983, s. 32; Deutsch, E. (çev. Yazman, İ. ) : Özellikle Deneysel Tıp Açısından Hekimin Sorumluluğu, AHFD, 1979, C. XXXVI, S. 1-4, s. 180.

148 Öztan, s. 121; Giesen, D. (çev. Özdemir, S.) : Yeni ve Deneysel Tedavilerden Dolay1 Doktorların Hukukî Sorumluluğu, Yargıtay Dergisi 1976, S. 1-2, s. 222.

${ }^{149}$ Şenocak, s. 13. Bu konuda ayrica bkz. Ott, s. 174; Reisoğlu, s. 4.
} 
başlığı altında zarar şartı hakkında yapılan açıklamalar burada da geçerlidir $^{150}$.

\section{ddd.Kusur}

Doktorun hukuka aykırı fiilinden doğan zararı tazminle yükümlü olması için kusurlu hareket etmiş olması gerekir (BK.m.41). Yalnız bu şart kusura dayanmayan bir sorumluluk türü olan BK.m.55 gereğince istihdam eden sifatiyla sorumluluğunda ve $\mathrm{m} .58$ gereğince eser maliki sifatiyla sorumluluğunda aranmaz ${ }^{151}$.

eee. Illiyet Băgl

Doktor sözleşmesel sorumlulukta olduğu gibi, haksız fiil sorumluluğunda da, hukuka aykırı davranışının ancak "genel hayat tecrübelerine, olayların normal akışına göre sebep olabileceği zararlı sonuçlarından" sorumludur ${ }^{152}$. Doktor davranışıyla uygun illiyet bağı içerisinde bulunmayan sonuçlardan sorumlu değildir ${ }^{153}$.

\section{c.Doktorun Sözleşmesel ve Sözleşme Dişı Sorumluluğunun Karşılaştırılması \\ aa.Genel Olarak}

Zarar veren fiil bazen hem sözleşmeye aykırı davranış hem de haksız fiil niteliğinde olabilir ${ }^{154}$. Doktorun amaca uygun olmayan bir tedaviyle sözleşme ilişkisi içerisinde bulunduğu hastanın bedensel bir zarara uğramasına sebep olması hali ${ }^{155}$ bu duruma örnek olarak verilebilir. $\mathrm{Bu}$ durumda doktor, tedaviyi öngören sözleşmeye aykırı davranmış olur ve doktorun sözleşmesel sorumluluğu ortaya çıkar.Ayrıca aynı durum, doktorla hasta arasındaki sözleşme dikkate alınmadığında, hukuk düzeninin herkese yönelttiği ve onlar tarafindan uyulması gereken "kimseye zarar verme" emri ihlâl edildiği için haksız fiil oluşturur. Yine doktorun tıbbi faaliyetlerin icrası

\footnotetext{
${ }^{150}$ Bkz. yukarıda, s. 26.

151 Şenocak, s. 13. Aslında BK.m.55 gereğince sorumlulukta, sorumluluğun kendisine bağlanmış olduğu objektif özen ve gözetim ödevinin ihlâli, kusurun biraz daha objektifleştirilmiş halinden başka bir şey değildir. Bkz. Tandoğan, Haluk : Kusura Dayanmayan. Sözleşme Dışı Sorumluluk Hukuku, Ankara 1981, s.54; Tandoğan, Haluk : Türk Mes'uliyet Hukuku (Akit Dışı ve Akdî Mesuliyet), Ankara 1981, s. 108.

${ }_{152}$ Şenocak, s. 14. Bkz. Eren, Fikret: Sorumluluk Hukuku Açısından Uygun İlliyet Bağı Teorisi, Ankara 1975, s. 21 vd. ; Reisoğlu, s. 9; Tandoğan, Türk Mes'uliyet..., s. 77; Honsell / Vogt / Wiegand: Kommentar zum schweizerischen Privatrecht, Obligationenrecht I, Art. 1529 OR, 2. Aufl., Basel 1996, Art. 41, N. 16; Gauch, P. / Schluep, W. R. : Schweizerisches Obligationenrecht, Allgemeiner Teil, (ohne ausservertragliches Haftpflichtrecht), Bd. II, 5. Aufl., Zürich 1991, N. 2715.

${ }^{153}$ Şenocak, s. 14.

${ }^{154}$ Bkz. Tandoğan, Türk Mes'uliyet ...., s. 528; Reisoğlu, s. 96.

${ }^{155} \mathrm{Bu}$ duruma örnek olarak, doktorun kusurlu bir ameliyat ile hastasını sakat bırakması hali verilebilir (Şenocak, s. 14).
} 
sırasında kullandığı yardımcı şahsın, sözleşme ilişkisi içerisinde bulunduğu hastaya zarar vermesi durumunda sorumluluk, BK.m.100 yanında, eğer doktorla müstahdem arasında "emri altında çalışma" ilişkisi mevcutsa BK.m.55'e de dayandırılabilir ${ }^{156}$.

$\mathrm{Bu}$ durumda hakların yarışması söz konusu olduğundan zarar görenin hangi sorumluluk sebebine dayanacağı sorunu ortaya çıkar. Doktrinde hâkim olan, Yargıtay ve Federal Mahkeme tarafindan da benimsenmiş olan görüşe göre, zarar gören dilerse sözleşmesel, dilerse sözleşme dış1 sorumluluk esasina dayanır ${ }^{157}$.

Ancak, sorumluluk sebeplerinin incelenip karşılaştırılmasından da anlaşılacağ halinde, sözleşmeye aykırı davranıştan doğan sorumluluğu düzenleyen kurallara dayanması genellikle daha yararlıdır ${ }^{158}$.

\section{bb. Pratik Sonuçları Yönünden}

Sözleşme ve sözleşme dışı sorumluluğun hukuki niteliklerinde özellikle bu iki sorumluluk sebebinin yarışması durumunda ortaya çıkan, önemli derecede farklılıklar mevcuttur. Bu farklılıklar şunlardır:

\section{aaa. İspat Yükü Yönünden}

İspat yükü, özellikle kusurun ispatı açısından önem taşır. Şöyleki, zarar gören haksız fiil sorumluluğunda, zarar vereni tazminata mahkum edebilmek için diğer sorumluluk şartlarıyla beraber, zarar verenin kusurunu da ispat etmek zorundadır. Buna karşılık sözleşmesel sorumluluğu düzenleyen BK.m.96'da ispat yükü ters çevrilmiştir. Bu maddede kusur karinesine yer verildiğinden borçlunun kusurlu olduğu farzedilir; kusurlu olmadığını ispat borçluya düşer.

T1bbi faaliyetlerden doğacak sorumlulukta doktorun kusurunun ispat1 çok zor olduğundan, bu iki sorumluluk sebebindeki ispat yükü düzenlemesinde mevcut bu farkl111k, sorumluluğun tesis edilip edilememesi bakımından önem taşımaktadır ${ }^{159}$.

bbb. Yardımcı Kişilerin Fiillerinden Dolayı Sorumluluk Yönünden

\footnotetext{
156 Şenocak, s. 14.

157 Şenocak, s. 14. Bkz. Tandoğan, Türk Mes'uliyet...., s. 537; Tekinay / Akman / Burcuoğlu / Altop,s. 981. HGK.nun 13.5.1953 t. ve 29-39 sayılı kararı için bkz. Olgaç, S. : Kazai ve İlmi İçtihatlara Göre Türk Medenî Kanunu Şerhi, 2. Bası, İstanbul 1969, md. 41, n. 209, s. 267; 4.6.1958 t. ve E. 1958 / 15, K. 1958 / 6 sayılı İBK için bkz. RG. 1.10.1958, N. 10021; Y. 11. HD’nin 20.9.1979 T. ve E. 1979 / 3398 , K. 1979 / 4053 sayılı kararı için bkz. YKD. 1980, S. 12, s. 1615 vd.; Federal Mahkemenin bu yoldaki kararları için bkz. BGE 71 II 18; BGE 64 II 254; BGE 57 II 265; BGE 60 II 118.

158 Senocak, s. 15.

159 Şenocak, s. 15.
} 
Doktorla hasta arasında bir sözleşme varsa, yardımcı şahısların fillerinden doğan sorumluluk BK.m.100'e dayanır. Buna karşılık, hasta ile doktor arasında sözleşmesel bir ilişki yoksa, bu sorumluluk BK.m.55'e dayanır. Yardımcı kişilerin fiillerinden doğacak sorumlulukta BK.m.55'e veya 100'e dayanmanın, yardımcı kişi kullanan kişinin kurtuluş kanıtı getirme olanağı açısından büyük önemi vardır. Doktor, sorumluluğun BK.m.55'e dayanması durumunda "zararın meydana gelmemesi için durumun gerektirdiği bütün dikkat ve özeni gösterdiğini veya dikkat ve özeni göstermiş olsaydı bile zararın doğmasına engel olamayacağını" ispat ederek sorumluluktan kurtulabilir. BK.m.100'den doğan sorumlulukta ise böyle bir olanak tanınmamış olduğundan, doktor yardımcı kişilerin fiillerinden doğan zarardan sorumluluğunu kurtuluş kanıtı getirerek ortadan kaldıramaz $^{160}$.

ccc. Zamanaşımı Yönünden

Sözleşmesel sorumlulukta zamanaşımı süresi kural olarak on y1ldır (BK.m. 125). Buna karşılık haksız fiil sorumluluğunda zamanaşımı süresi, zarar görenin zararı ve haksız fiil failini öğrendiği tarihten itibaren bir yıldır (BK.m.60).

\section{B.Doktorun Sorumluluğunda Şans Kaybı Bakımından Yargıtay}

\section{Kararlart}

\section{Genel Olarak}

Türk hukukunda doktrinde şans kaybı ve bundan doğan zarar üzerinde durulmamıştır. Yargıtay'ın son yıllarda özellikle doktorların sorumluluğu ile ilgili verdiği bazı kararlarda şans kaybı teorisinin etkisi olduğu kanaatindeyiz; ancak bu kararlardan açıkça bu teorinin kabul edildiği anlaşılamamaktadır. Aşağıdaki Yargıtay kararlarına konulan başlıklar, açıkça kararlarda yer alan ifadeler olmayıp, bizim kişisel değerlendirmemizi yansitmaktadir.

\section{Doktorun Sorumluluğunda Şans Kaybu ile ilgili Yargıtay Kararları}

\section{a.Yaşama Şansının Kaybına İlişkin Yargıtay Kararı}

Yargitay 13.Hukuk Dairesi, 10.11.2003 tarih 2003/13964-13347 sayıl1 yayımlanmamış kararında, doktorun kontrolünde hamilelik devresini geçiren

\footnotetext{
${ }^{160}$ Şenocak, s. 15-16. Ancak BK.m.100'e göre borçlu (doktor), yardımcı kişinin fiilinin, eğer bunu yardımcı kiși yerine kendisi yapmış olsaydı, bunun kendisine bir kusur olarak isnat edilemeyeceğini ispat etmek suretiyle sorumluluktan kurtulabilir. Bunun yanında borçlu her zaman illiyet bağını kesen sebeplere (üçüncü kişinin kusuru, zarar görenin kusur, mücbir sebep) dayanarak sorumluluktan kurtulabilir.
} 
ve doktor tavsiyelerine göre hareket eden davacı kadının doğum yaparak çocuğun kalp hastası olduğu ve zamanında küveze alınmadığı ve doktorlar ve hastanenin kusurlu olduğundan bahisle açılan maddi ve manevi tazminat davasında davanın reddine dair verilen mahkeme kararı Yargıtayca dosyada bulunan rapor ve tıbbi belgelere göre doktorun kusur oranının ve davalı hastanenin de Borçlar Kanunu md.55'e göre adam çalıştıran sıfatıyla sorumluluğunun belirlenmesi yönünden yeniden uzman bilirkişi kurulu raporu alınarak sonucuna göre bir karar verilmesi gerekirken hastane hakkında davanın reddine dair verilen karar usul ve yasaya aykırı bulunarak bozulmuştur. Kanaatimizce, Yargıtay'ın bu kararı yerindedir, zira çocuğun doğumundan önce ve doğumundan sonra gerekli özenin ve tıbbi tedavilerin yapılmış olması halinde çocuğun yaşama şansı olacağı ihtimali kuvvetlidir. Ayrıca Yargıtay kararında “......Mahkemece hükmüne dayanak alınan..... tarihli Adli Tıp raporunda belirtildiği üzere İ.Ü.Cerrahpaşa Tıp Fakültesi Kadın Hastalıkları ve Doğum Anabilim Dalı Başkanlığı.......tarihli ve .sayılı raporunda bebeğin ölümünün doğuştan kalp hastalığ1 ve bunun getirdiği sorunlar nedeniyle oluştuğu, bahsi geçen kalp hastalığının gebelik esnasında teşhis edilmesi ve ailenin bu durumdan haberdar edilmesiyle bebeğin doğar doğmaz yoğun bakıma alınarak sürekli tedbirlerin alınması ve gerektiğinde düzeltici operasyonlar yapılmasıyla bebeğin yașam șansının artacağ1, bu nedenle sonuçta hastayı tüm gebelik boyunca izleyen ve doğumsal kalp damar hastalığı teşhisini koymakta yetersiz kalan doktor A.N.'nin (dava dışı doktor) sorumlu olduğu belirtilmektedir." Burada işaret etmek istediğimiz husus, Yargıtay'ın bu kararında "bebeğin yaşam şansının artacağı" ifadesine yer vermesidir. Burada, yaşama şansının kaybedilmesi dolayısıyla annenin ve babanın tazminat haklarının olduğu kabul edilmelidir. Karart

b.Sağlıksız Bir Çocuğa Sahip Olmama Şansının Kaybı İle İlgili Yargıtay

Yine Yargitay 13. Hukuk Dairesi'nin 25.12.2003 tarih 2003 / 10757 15490 sayılı yayımlanmamış kararında, "davacılar N.A ve M.A. davalı doktorun aleyhine açtıkları maddi manevi tazminat davasında, davacı N.'nin annesi babası arasında akraba evliliği bulunması, dayısının Down sendromlu bir çocuğunun olması ve N.'nin skelyoz hastalığı geçirmiş bulunması nedeniyle doğacak çocuklarının özürlü olması endișesiyle davalı doktora gittiklerini, davalının (doktorun) doktor kontrolünde bir hamilelik ile kötü sonuçların önlenebileceğini bildirmesi nedeniyle davacı N.'nin hamile kalarak doktor kontrolünde doğum yaptığını, ancak doğan çocuklarının Down sendromlu olduğunun anlaşıldığını; davalı doktorun bu rahatsızlığın tespiti için varolan üçlü tarama testi ve amniyosentez testlerini önermediğini davalının kusuru nedeni ile Down sendromlu çocukları olduğunu,çocuğun eğitim, bakım ve sağlık harcamaları ile destekten yoksun kalma zararlarının oluştuğunu ileri sürerek her bir davacı için 25 milyar TL manevi, 5 milyar TL maddi tazminatın yasal faiziyle tahsilini istemişlerdir. 
Davalı, hamilelik boyunca tüm kontrolleri yaptığını, ultrason incelemesinde şüpheli bir durum tespit edilmediğini, üçlü test ve amniyosentezin de riskleri bulunduğunu, hekim olarak kendisine izafe edilecek bir kusur bulunmadığını savunarak davanın reddini istemiştir.

Mahkemece, Adli Tip Genel Kurulu'nun .........tarihli raporu benimsenerek davalının 1/8 oranında kusurlu bulunduğunu kabul ederek davacıların yaptıkları harcamalar nedeniyle kusuru oranında 276.710.745 TL maddi tazminatın dava tarihinden itibaren yasal faizi ile tahsiline her bir davac1 için 5.000.000.000 TL manevi tazminatın dava tarihinden itibaren yasal faizi ile tahsiline, fazlaya ilişkin maddi ve manevi tazminat taleplerinin reddine karar verilmiş; hüküm, taraflarca temyiz edilmiş; Dairemizce 23.5.2003 tarihinde düzeltilerek onanması üzerine, bu kez davacılar vekili karar düzeltme talep etmiştir.

1.Temyiz ilâmında belirtilen gerektirici nedenler karşısında usulün 440 . maddesinde sayılan nedenlerden hiçbirisine uygun olmamasına göre davacılar vekilinin aşağıdaki bendin kapsamı dışında kalan sair karar düzeltme isteğinin reddi gerekir.

2.Davacılar, davalının kusuru ile Down sendromlu bir çocuklarının olduğunu, Down sendromlu bir çocuğun ileriye dönük bakım, tedavi ve eğitim masraflarının normal bir çocuğa nazaran fazla olacağını ileri sürerek maddi tazminat isteminde bulunmuşlardır. Mahkemece davacıların bu istemleri hakkında bilirkişiden rapor alınmamış, sadece bugüne kadar yapılan masraflar gözetilerek bir hesaplama yapılmıştır. Oysa Down sendromlu bir çocuğun normal bir çocuğa göre daha fazla bakım, tedavi ve özel bir eğitim masrafı olacağı tabiidir. Mahkemece bu konuda uzman bir bilirkişiden rapor alınarak ileriye yönelik olarak davacıların çocuklarının normal bir çocuğa yapılması gereken masraflar dışındaki bakım, tedavi ve özel eğitim masraflarının tespiti ile bu kalem yönünden istenebilecek maddi tazminat miktarının belirlenerek hüküm altına alınması gerekirken, bu yöndeki talebin reddine karar verilmesi doğru değildir. Dairemizce kararın davacı yararına bu nedenle de bozulması gerekirken zuhulen vekâlet ücretinden düzeltilerek onandığ 1 bu kez yapılan inceleme sonucu anlaşılmıştır. O halde, davacıların karar düzeltme istemi kabul edilerek Dairemizin 23.5.2003 tarihli düzeltilerek onama kararı kaldırılarak, mahkeme hükmünün açıklanan nedenlerle davacılar yararına bozulması gerekmiştir.

SONUÇ: Davacıların sair karar düzeltme isteminin 1 nolu bentte gösterilen nedenle reddine, 2 nolu bentteki nedenlerle davacıların karar düzeltme isteminin kabulü ile Dairemizin 23.5.2003 gün, Esas 2003 / 3159, Karar 6184 sayılı düzeltilerek onama ilâmının kaldırılmasına, mahkeme kararının açıklanan nedenlerle de davacı yararına BOZULMASINA, 
25.12.2003 gününde oybirliğiyle karar verildi"şeklinde hüküm tesis edilmiştir.

Bu hükmün içeriğinden de açıkça anlaşılacağ 1 üzere, hastayı aydınlatma yükümlülüğü ve hamilelik esnasında gerekli tıbbi test ve incelemeleri yapmakta doktorun kusurlu olduğu kabul edilerek davacıların yaptıkları tüm masraflar ile Down sendromlu doğan çocuğun normal çocuğa nazaran eğitim ve bakım masraflarının fazla olacağı nazara alınarak bilirkişi marifetiyle zararın tespit edilerek davalı doktorun kusuru oranında hüküm tesisi gerektiği kabul edilmiş, ancak ana babanın çocuktan ileride alacağı destek kaybı yönünden bir tazminat öngörülmemiştir. Kanaatimizce, Yargitay'ın bu karar1 Down sendromlu çocuğun normal çocuğa nazaran bakım, tedavi ve özel eğitim masraflarının daha fazla olacağı dikkate alınarak maddi tazminata hükmedilmesi gereği yönünden mahalli mahkeme kararının bu konuda bilirkişi incelemesi yaptırılarak karar verilmesi gereği ile bozulmasına karar vermesi yerindedir. Zira, davalı doktor Yargitay kararında belirtilen üçlü tarama testi ve amniyosentez testlerini hamilelik esnasinda yapmış olsa idi, çocuğun Down sendromlu doğacağını anlaması mümkün olduğundan çocuğun doğmaması için önlem alınabilecekti. Doktorun doğacak çocuğun Down sendromlu olduğunu teşhis etmemesi ve önlem almamasında kusurlu olduğu, diğer bir ifadeyle, gerekli dikkat ve özen yükümlülüğünü yerine getirmediği Yargıtayca da kabul edilmiştir. Kanaatimizce, davalı doktor davacıların sağlıksız bir çocuğa sahip olmama şanslarını kaybetmelerine neden olmuştur. Bu durum, Yargitay kararında açıkça şans kaybı olarak nitelenmemiş̧ir. Ancak, kanaatimizce bu olay, şans kaybını inceleyen tıbbi sorumluluk literatüründe "sağlıksız bir çocuğa sahip olmama şansının kaybı ("Wrongful birth") ${ }^{161}$ olarak adlandırılan şans kaybının tipik örneğidir. Yargıtay'ın bu kararında durumu açıkça "şans kaybı" olarak nitelendirmemesine rağmen zımni olarak bu şans kaybını kabul ettiği görüşündeyiz.

\section{c. Iyileşme Şansının Kaybı İle İlgili Yargıatay Kararı}

Yargitay 13. Hukuk Dairesi'nin 16.9.2003 tarih 2003 / 6060- 10174 sayılı yayımlanmamış kararında, davacı davalı doktor tarafından tespit edilen gebeliğin 20.4.2000 tarihinde kürtajla sona erdirildiğini, ancak 15.5.2000 tarihinde karın ağrısı, ishal, tansiyon düşüklüğü şikayeti ile hastaneye kaldırıldığını, hastanede sekiz haftalık dış gebelik saptanarak acil ameliyata alındığını, kendisinde zamanında dış gebelik teşhisi konulamaması sonucu hayati tehlike atlattığını ileri sürerek maddi ve manevi tazminat talebinde bulunduğu, davalı doktorun ise, davacıda beş hafta dört günlük iç gebelik saptandığını ve iç gebeliğin 20.4.2000 tarihinde tahliye edildiğini, bir hafta sonra kontrole geldiğinde hiçbir şikayetinin olmadığını, dış gebelik

161 "Wrongful Birth" kavramı hakkında ayrıntılı bilgi için bkz. VI / A başlı̆̆ı altındaki açıklamalar. 
belirtilerinin bulunmadığını ve hastayı on beş gün sonra tekrar çağırmadığını savunarak davanın reddini istediği, mahkemece ise toplanan delillere göre davanın reddine karar verildiği, davacı vekilinin temyizi üzerine adı geçen Yargitay Dairesince dosyadaki raporlar ve bu raporlardan Adli T1p Raporu ve dosyada bulunan diğer raporların incelenmesi ve karşılaştırılması sonucu iç gebelikle beraber dış gebeliğe de nadiren de olsa rastlanabileceğinin anlaşılmasının mümkün olacağı kabul edilerek mahkemece bu yönde gerekli özenin gösterilmesi bakımından üniversite öğretim üyelerinden oluşturulacak bilirkiş̧i kurulu aracılığıyla davacıya ait tüm raporlar dosyaya ibraz edilerek tüm rapordaki görüşler de göz önünde tutularak rapor alınması ve sonucuna göre karar verilmesi gerektiği belirtilerek mahalli mahkeme kararı bozulmuştur. Kanaatimizce, Yargıtay'ın bu bozma kararı yerindedir; zira davalı doktorun yeni teşkil edilecek uzman bilirkişi kurulu aracılığıyla özen gösterme ve aydınlatma yükümlülüğünü yerine getirip getirmediğinin araştırılması gerekir. Burada davacıda eğer iç gebelikle dış gebelik aynı anda teşhis edilmiş ve her ikisi de aynı anda tahliye edilmiş olsa idi, davacı hayati tehlike geçirmeyecekti ve tedavi süresi uzamayacaktı. Yapılacak bilirkişi incelmesine göre doktorun sorumluluğunun olup olmadığı belirlenecektir. $\mathrm{Bu}$ olayda, doktorun ihmali ve özensizliği olduğunun bir an için tespit edileceğini varsayarsak, böyle bir halde bir iyileşme şansının kaybı söz konusu olabilir mi? Bunu tartışmak gerekir. Her ne kadar Yargıtay, kararında şans kaybından bahsetmemişse de (zaten esas hakkında bir karar tesis etmeyip davayı tahkikatın genişletilmesine sevk etmiştir), tedavinin gecikmesi suretiyle iyileşme şansının kısmen kaybedildiği düşünülebilir kanısındayız.

VI.Tıbbi Sorumluluk Bakımından Şans Kaybı Hususunda Özel Surette Tartışılan Birkaç Uygulama

\section{A. Bir Çocuğun Olmamasında "Şans" Kaybı ( "Wrongful birth") ${ }^{162}$}

\section{Kavram}

"Wrongful birth" ifadesi, planlanmamış veya istenmeyen bir çocuğun doğumu ile ilişkili ebeveyinlerin uğradığı zarar ile ilgilidir ${ }^{163}$. Talep, istenmeyen doğumun psikolojik ve malvarlığına değin sonuçlarının hukuki planı üzerinde (örneğin tecavüzcü, başarısız bir çocuk düşürme veya kısırlaştırma durumunda doktor) sorumlu olan üçüncü bir şahsa karş1

\footnotetext{
${ }^{162} \mathrm{Bu}$ konuda ayrıntılı bilgi için bkz. Stieglitz, Susanne : Die wrongful birth und wrongful life Problematik im deutschen Deliktsrecht, München 1989.

${ }^{163}$ Tobler, Christa / Stolker, Carel : "Wrongful Birth"- Kosten für Unterhalt und Betreuung eines Kindes als Schaden, 6 PJA (1997) s. 1145; "Wrongful Birth"'ün tanımı için ayrıca bkz. Black's Law Dictionary, 6. Ed., St. Paul 1990, s. 1612. Bu konuda ayrıntılı bilgi için bkz. Mannsdorfer, Thomas M. : Pränatale Schädigung - Ausservertragliche Ansprüche pränatal geschädigter Personen, thése, Freiburg 2000, N. 925, 976 vd.
} 
yöneltilir. Birçok ülkede, zararın ne ile ilgili olduğunu bilmek sorusu ile ilgili bir tartışma söz konusudur: Hamilelik masrafları, doğum masrafları, bebek için ekipman masrafları, daha büyük bir daire masrafı, bakım masrafları ve eğitim masrafları, yeni bir kısırlaştırmaya bağlı masraflar. Özellikle bazen annenin hamilelikten, doğumdan meydana gelen bir maddi olmayan zarar söz konusudur. "Wrongful birth" için bir eylemden meydana gelen zararın en tartışılır yeri, çocuğun bakım masrafları ve eğitim masraflarıdır, çünkü burada çocuğun kendisinin bir zarar olup olmadığı söz konusudur. Yabancı hukuklar bu soruya çok farklı cevaplar vermişlerdir ${ }^{164}$.

\section{Mevcut Durum}

İsviçre'de, bu tür davanın açılmış olduğu nadir mahkemeler, istenmemiş olan bir çocuğun doğumu ile ortaya çıkan bakım masrafları ve eğitim masraflarını tazmin etmeyi reddetmişlerdir. Bu başlık altında yapılan açıklamalar, sorunun ortaya çıkartmış olduğu ahlâki ve felsefi, manevi bir çok soruları gündeme getirdiğinden, İsviçre mahkemelerinin bununla ilgili kısıtlayıcı tutumlarını tartışma imkânı vermemektedir. Bir şansın kaybı teorisi ile iyi bir şekilde çözümlenebilecek olan "Wrongful birth" için çok spesifik bir talep ortaya koymakla ilgili olacaktır, burada ebeveynlerin bir üçüncü şahsın kusuruyla bir hamilelik durdurmasını yapma imkânından yoksun kaldıkları varsayımı söz konusudur. Bu kusur bazen, bir doktor tarafindan aydınlatma yükümlülüğünün ihlâlinde mevcuttur. RUETSCHI, bu durumda, illiyet bağı sorusunun bu anlamda bir kanıt sorunu oluşturduğunu düşünür. Her somut durumda, bu soruya cevap vermek, mahkemelerin görevidir. Federal Mahkeme, çocuğun bakım masrafının tazmin edilebilir zarar olarak kabul edilip edilmeyeceğini bilmek sorusunu açık bırakmak için bugüne kadar kendisine verilen olayların durumlarından faydalanmıştır. 1995 yılında yayımlanmayan bir kararda, hamilelikten meydana gelen zarar ve kısırlaştırma işlemi esnasında hamilelik riskleri hakkında aydınlatma yükümlülügü arasında illiyet bağını inkâr etmiştir. Nedeni, eşlerin, hamileliğin çok zayıf kaçınılmaz risklerini bilerek, gebeliği önleme yöntemi için karar vermiş olmalarıdır ${ }^{165}$.

\section{Alman Hukuku}

Almanya'da ya hep ya hiç prensibiyle durum bir kez daha çözümlenmiştir. Eğer doktor, ebeveynleri bir doğuma bağlı bazı yanlış formasyon risklerini bildirmekten kaçınırsa, ağır bir şekilde özürlü bir çocuğun doğumunu engellemeye adanan bu bilgi yetersizliğinden sorumludur ${ }^{166}$. Bu durumda, çocuğun bakım masrafları pratisyen doktor

\footnotetext{
${ }^{164}$ Müller, s.360 - 361, N. 529.

${ }^{165}$ Müller, s.361-362,. N. 530.

${ }^{166}$ BGH, 4 März 1997, 50 NJW (1997) s. 1640; Deutsch, Erwin : Medizinrecht, 4. Ed., Berlin

/ Heidelberg / New York 1999, N. 277.
} 
tarafından karşılanacaktır ${ }^{167}$. Genetik bir kusuru olan çocuğun doğum riskleri hakkında verilen hatalı bir bilgi için aynı şey geçerlidir ${ }^{168}$.

\section{Fransız Hukuku: Bir şansin kaybı}

Fransız hukukunda, ebeveyinler, bir IVG'ye başvurarak anormal bir çocuğu doğurmamak şansından yoksun olduklarından dolayı şikayette bulunabilirler. Bir hamileliğe müdahale etme şansının kaybı, üçüncü bir şahıs (bir medikal analiz laboratuvarı tarafından yapılan hata) veya doktor tarafından işlenen bir hata (teşhis yanlışı) veya pratisyen tarafından yapılan bilgi hatası gibi nedenlerden olabilir.Her üç durumda, tazminatın amacı, doğacak çocuğun sağlık koşulları ile ilgili alınan bilgilerle hamileliğe son vermektir, yani bir "zarardan" kaçınılacak bir karar almaktır. Bu şekilde, ebeveyinler açık bir karar alma şansını kaybettikleri zaman, bu şans kaybı, eksik bilgi verenler tarafindan tazmin edilir. Benzer bir olay, 1989 yılında Montpelier Asliye Hukuk Mahkemesinde söz konusu olmuştur. Bir kadın, doğacak olan çocuğun durumunu öğrenmek için bir inceleme yaptırır. Montpelier Asliye Hukuk Mahkemesine göre, eksiklik uygulanan incelemede kabul edilen güvenilirlik derecesinin yanlış bir değerlendirmesinden meydana gelmiştir. Hâkimler "çocuğun anne ve babası tarafindan yaşanan zararın, bir hamileliğe son verme uygulaması şans kaybı olarak tanınabilir" olarak karar vermiştir. Müller'e göre, "böyle bir olayın kabulünün Avrupa İnsan Hakları Sözleşmesinin 2. maddesine uymadığını", belirtmek gerekir ${ }^{169}$.

Yakın zamana kadar, ağır bir şekilde beklenmeyen özürlü bir çocuğun doğmas1 ile meydana gelen manevi sarsıntılar gibi doğumun normal yükümlülüklerini aşan özel bir zararın eklenmesi gerekmekte idi ${ }^{170}$.

\section{B.Doğmaktan Dolayı "Şans" Kaybı ("Wrongful life") $)^{171}$}

\section{Kavram}

$\mathrm{Bu}$ varsayım, benzer durumları göstermektedir: Doğumdan önce annenin yanlıș tedavisi, genetik inceleme çerçevesinde yanlıș teșhis. Davacı, burada prensip olarak "doğmamam gerekir idi" eyleminde ve bir yanlış

\footnotetext{
${ }^{167}$ BGH, 4 März 1997, 50 NJW (1997) s. 1640; Geiss, Karlmann / Greiner, Hans - Peter : Arzthafpflichtrecht, 3.Aufl., München 1999, B 175.

${ }^{168}$ Müller, s. 362, N. 531; Steffen, Erich / Dressler, Wolf-Dieter : Arzthaftungsrecht, 8. Aufl., Köln 1999, N. 295.

${ }_{169}$ Müller, s.362 - 363, N. 532.

${ }^{170}$ Müller, s.363, N. 532. Tazmin etmenin kabulü için İsviçre hukukunda, bir çocuk sahibi olmadığında şans kaybı için bkz. Müller, s.367-368, N. 540.

${ }^{171} \mathrm{Bu}$ konuda ayrıntılı bilgi için bkz. Stieglitz'in yukarıda s.34, dn. 165 'de anılan eseri ve Picker, Eduard : Schadensersatz für das unerwünschte eigene Leben "Wrongful Life", Tübingen 1995.
} 
tedavi nedeniyle özürlü çocuktur. "Wrongful life" ve "Wrongful birth" için yapılan talepler arasındaki fark her zaman belirgin değildir. Nadir olarak, çocuğun kendisine "wrongful life" için bir talep hakkı tanınır. Buradaki değerlendirmeler, yalnızca doğmama imkânından üçüncü bir şahıs (örneğin bir medikal inceleme laboratuvarı) veya doktorun yapmış olduğu hata ile çocuğun yoksun olduğu doğmama şansı varsayımıyla ilgilidir ${ }^{172}$.

\section{Mevcut Durum}

İsviçre içtihad1, çocuğun kendisine böyle bir talep hakkı tanıma sorusu üzerinde asla karar vermemiştir ${ }^{173}$.

\section{Diğer Ülkeler}

Almanya'da, "wrongful life" için bazı talepler, bu durumlarda hukuki manada bir sorumluluğunun artık uygun olmadığını kabul ederek, genel olarak reddedilmiştir.

Amerika Birleşik Devletlerinde, bu taleplerin artık kabulü söz konusu değildir. Yalnızca dört Federe Devlet, çocuğa bağımsız bir talep hakkı tanımışlardır, burada da çözüm, ilgili aileler lehine tazminatı kabul ettirmek için tek yol bu idi.

Bütün bu kararlarda, yalnızca özüre bağlı ek masraflar tazmin edilmiştir ${ }^{174}$.

\section{Fransız içtihadı}

Uzun zamandır, doğmuş olmak olayı, zarar olarak çocuğun kendisi tarafından talep edilmesi düşünülemez idi, çünkü :

"Eğer bir insanoğlu, hak sahibi ise, doğmuş olmak veya olmamak olgusu, yaşamak veya yaşamamak olgusu önem taşımamaktadır ve doğumu veya yaşam süresi bir şans veya şans kaybı olarak kabul edilemez".

Bir çocuk, bu şekilde, annesi için, bir IGV'ye karar vermek veya vermiş olmaktan, gecikmelerden şikayet edemez idi. Devlet kurulu bu olayı, 15 şubat 1997 tarihli bir mahkeme kararında kesin olarak kabul etmiştir. Fakat, Yargıtay, 1996 yılında aynı gün içerisinde verilen iki mahkeme kararında , "wrongful life" için bir talep imkanı muhafaza ederek bu ontolojik (varlık bilimi) kilidini atlatmıştır ${ }^{175}$.

5. İlk durumda, 1982 yılında, eşler, özrü olan bir babanınkine benzer nörolojik rahatsızlıklara sahip bir çocuğa sahip olma riski hakkında bir tıp doktoruna başvururlar. Doktor, uygun bir genetik tavsiyesinde bulunur. 1987 yılında, kadın, babasınınkine benzer bir özürlü çocuğu dünyaya getirir. Ebeveynlerin talebi üzerine, istinaf mahkemesi, çocuğun olduğu

\footnotetext{
172 Müller, s.363-364, N. 534.

${ }^{173}$ Müller, s.364, N. 535.

${ }^{174}$ Müller, s.364 - 365, N. 536.

${ }^{175}$ Müller, N. 537.
} 
kadar ailenin de zararının tazmin edilmesi bakımından doktorun sorumluluğunu kabul etmiştir. Her iki durumda, istinaf mahkemesi, çocuğun zararının tazmin edilmesini onaylamışıır ${ }^{176}$.

6. İkinci türde, dört y1l sonra, devamında bulunan olaylar tazminat talebi bazında bulurlar : bir çocuk bekleyen bir kadın kızamığı düşündüren bazı belirtiler gösterir. Böyle bir durumda, çocuğu tehdit eden yanlış formasyonların ağır risklerini bilmekte olup, kendisi bu hastalığa sorumlusu laboratuar ve doktorunun hataları, bağışıklık olduğuna inandırmıştır. Halbuki, kendisinde kızamık söz konusudur ve çocuğun doğmasından kısa bir süre sonra, kendisinin nörolojik ve duyumsal rahatsızlıklarının bulunduğu görecektir. Doktor ve laboratuara karşı, ebeveynler kendi zararlarının tazminine ilişkin dava açarlar ve çocuğun adına bir ikincisini açarlar. $\mathrm{Bu}$ ikinci talepte, asliye hukuk mahkemesi kararı, istinaf mahkemesi tarafından geçersiz kılınır. Bunun nedeni ise, yakalanmış olduğu rahatsızlıklar, annenin kendisine aktarmış olduğu in utero kızamıktır. $\mathrm{Bu}$ mahkeme kararı, Yüce Divan tarafından 26 mart 1996 tarihinde bozulmuştur. Dava Orlean istinaf mahkemesine gönderilmiştir. Mahkeme "çocuğun doktor ve laboratuarın yapmış olduğu hatalardan dolayı tazmin edilmesi gereken zarara uğramadığını beyan eder". Tekrar Yargıtay’a gidilir, zorunlu olarak toplanmış vaziyette. CCF 1165 ve 1382 maddeleri uyarınca, kurul şu kararı verir :

"Bayan X ile oluşturulmuş sözleşmelerin icrasında laboratuar ve doktor tarafindan uygulanan yanlışlık esnasında özürlü bir çocuk doğurmaktan kaçınmak için engelleme söz konusu olduğunda, kendisi tutulan hatalar ile sebebiyet verilmiş ve bu özürden meydana gelen zararın tazminini talep edebilir"

Muhakeme, toplu bir heyecan ile olmuştur ve jüri topluluğunda çok canlı bir duruşma meydana getirmiştir. TOURNEAU / CADIET, zararın özürlü doğma olayından ibaret olamayacağını düşünmüştür, çünkü yazarlara göre, bu özür tıbbi uygulama hatalarından meydana gelmemişti. Sonuç olarak, zarar, doğmama şansından yoksun kalma olayı dolayısıyla söz konusu olabilir ${ }^{177}$.

\section{Kabul}

"Wrongful life" veya "wrongful birth" için sorumluluk durumlarında bir şans kaybı teorisinin uygulanabirliliği, bu teoriye özgü incelemeye bağlı değildir. İstenmeyen bir çocuğun doğumunu tazmin edilebilir bir zarar olarak nitelemenin mümkün olup olmadığı sorusu, İsviçre hukuk sistemine göre cevaplandırılacaktır. Eğer olumlu olarak cevap veriyor isek, bir hamileliği engelleme şans kaybı, Fransız içtihadının vermiş olduğu örneklerle tazmin edilmelidir. Ancak, eğer buna olumsuz olarak cevap

\footnotetext{
${ }^{176}$ Müller, N. 538.

${ }^{177}$ Müller, N. 539.
} 
veriyor isek, bir şans kaybı teorisi, zararın olmadığ 1 bir sonuca ulaşmaktayız. Gerçekten de, şans kaybının son zarardan bağımsız bir zarar olduğunu düşünsek bile (istenmeyen çocuğun doğumu), kaybedilen şans değerinin son zarara göre hesaplanması olayı (sıfira eşit olacak durumda), bu kaybedilen şans değerinin sıfira eşit olması sonucunu verir ${ }^{178}$. Bu sorun bu çalışmanın çerçevesini aşan çok ilginç antropolojik ve felsefî sorular ortaya koyar. Doktrinin bir kısmı, "wrongful birth" için talepler ile ilişkide olan bir şans kaybının tazminatının, doğmak veya doğmamak olayının sübjektif bir hukuku tanımamızı ortaya koyar. Burada, doktorlara, bir doğmama şansını kaybettirmelerinden yakınırdık. O zaman "uygun değilse doğmamak" gibi bireyin bir hakkı ile ilgilidir. Ne olursa olsun, şunu anlamak çok zordur : neden bir sakatlık hamilelik esnasında üçüncü bir şahıs tarafindan işlenen bir hatada olduğunda değil de, yalnızca doğumdan sonra yaşandığ 1 zaman tazmin edilebilir ${ }^{179}$.

\section{Yaşam veya Ömür Şansının Kaybı}

\section{Varsayım}

Eğer yaşama bir hak ise, mutlak koruma (Federal Anayasa Md. 10), hatalı bir davranış ile kısaltılması, daha uzun yaşama şansının kaybı için bir tazminatı teorik olarak doğrulayabilir. Bu durum iki şekilde açıklanabilir. Önce, yaşayan mağdur, kaza sonucu meydana gelen yaşam kısaltılması için bir tazminat talep edebilir. Daha sonra, kısaltılma olayı, mirasçılar tarafindan talep edildiğinde teorik olarak bir tazminat söz konusu olabilir ki, burada mağdur kaza sonucu vefat etmiştir ${ }^{180}$.

\section{Fransız içtihadı : Doğrudan Măgdur}

Bir yaşam umudunun kaybını tazmin eden diğer hukuki sistemler (loss of expectation of life) veya ölümden meydana gelen zarar (pretium motris), burada Fransız hukuku kendisini yeterince k1sitlayıcı göstermektedir. 1967 yılı Yargıtay kararı, genel bir istisna oluşturmaktadır :

"Tıbbi ekspertiz üzerine kurulan mahkeme kararı, genç adamın bir splenektomi yaşadığını saptaması ile, mağdurun bir yaşam sonucunu saptamasıyla, bu risk sebebiyle, burada tazminat talep edilmişti”. Yargıtay bu talebi kabul etmişti.

MÜLLER'e göre, Yargıtay bir yaşama şansının kaybını açıkça belirtmemiş olsa bile, bu karardan başka bir anlam çıkarılması mümkün değildir. Doktrin tarafından hakkında hiçbir yorum yapılmayan karar, izole bir karar oluşturur gibidir ${ }^{181}$.

\footnotetext{
${ }^{178}$ Bkz. Müller,s. 380, N. 564.

${ }^{179}$ Müller, s. 367-368, N. 540.

${ }^{180}$ Müller, s.368, N. 542.

${ }^{181}$ Müller, s.368, N. 542.
} 


\section{Fransız içtihadı : Dolaylı Mağdur}

Aşağıdaki dava, ölenin mirasçıları (dolaylı mağdurlar) tarafından kaybedilen uzun yaşama şansları için bir tazminat talep edilip edilemeyeceği sorusunu ortaya çıkardı. Bir araba kazası geçiren bir kadın, yaraları nedeniyle kazadan birkaç gün sonra vefat eder. Kusurlu otomobil sürücüsü, taksirle adam öldürmek suçundan mahkum edilir ve kazanın tazmin edilebilir sonuçlarından tamamıyla sorumlu olduğuna karar verilir. Rennes İstinaf Mahkemesi, müdahil taraf olarak duruşmaya çıkan mirasçılara kendilerinin şahsen maruz kaldıkları ve doğrudan doğruya kazadan kaynaklanan manevi ve maddi zararın tazmini anlamında zarar- ziyan tazminatı tahsis etti. Buna karşılık mahkeme, davacılara göre ölenin kaza yüzünden maruz kaldığı bir hayat şansının kaybından kaynaklanan zararın tazmin edilmesini amaçlayan tazminat talebini reddetti. İstinaf Mahkemesinin yargıçları, mirasçıların ileri sürdükleri yaşam umudu kaybının gerçekleştiği an olan mağdurun ölümünden önce, Carnet adındaki kadının malvarlığına hiçbir tazminat hakkının girmemiş ve malvarlığına intikal ettirilmemiş olduğunu söyleyerek bu talebi reddettiler. Temyiz Mahkemesinin Ceza Dairesi, aynı gerekçelere dayanarak bu içtihadı onayladi ${ }^{182}$.

\section{Değerlendirme}

Bir uzun ömür şansının kaybının tazmini haklılık arzetmez, zira kazanılacak toplam şeyin şüpheli özelliği eksiktir ${ }^{183}$. Hatta eksik olan, kazanılacak toplam şeydir, zira olduğu şekliyle hayat bir şahsın kaybı olarak bir tazmine mahal verilebilen bir kazanilacak ya da kaybedilecek şey oluşturmaz. Ölmemekten başka şansı olmayan kişinin durumu, ölme şansı olan kişininki ile aynı değildir. Kaza bir "yaşam şansı" n1 ortadan kaldırmıyor ve bir şansın kaybedilmemesinin zararı bu davalarda son zarar ile, ölüm ile karışıyor.Doğrudan mağdur böylece vefatından önce malvarlığında bir yaşam şansına sahip olmadığı için dolaylı mağdurlar da miraslarında bu hakkı alamazlar ${ }^{184}$.

\section{D.Măgdurun Birlikte Kusuru İle Bir Şansın Kaybı}

\section{Sorun}

Bazen mağdur bizzat kendi kendisini bir şanstan mahrum eder. Tibbi sorumluluk alanındaki tipik örnek, iyileşmesi ya da hayatta kalması için "nesnel bir şekilde" zorunlu olan bir tedaviyi reddeden hasta örneğidir. Bu varsayımda, bizzat kendisini bir iyileştirme veya hayatta kalma şansından mahrum eden mağdurun, davranışına sorumlunun ona borçlu olacağı tazminatın azaltılması neticesine izin verip vermeyeceğini bilme sorununu ortaya çıarmaktadır ${ }^{185}$.

\footnotetext{
182 Müller, s. 369, N. 543.

${ }^{183}$ Bkz. Müller, s. 254, N. 369 vd.

184 Müller, s. 369, N. 544.

${ }^{185}$ Müller, s. 369, N. 545.
} 


\section{Fransız İçtihadı}

Temyiz Mahkemesinin Ceza Dairesi tarafından sonuca bağlanan bir davada, bir kazanın mağduru hiçbir engelli durum (kontrendikasyon) arz etmeyen ve muhtemelen onun sağlık durumu üzerinde önemli bir iyileştirici etkisi olacak bir ameliyata razı olmayı reddetti.Temyiz mahkemesi, "yargıçların mağdura onun kabul etmeyi reddettiği ameliyatı empoze etmeye yetkili olmadıklarına ve böyle olunca bu redde dayanarak, mağdurun katlanmış olduğu zararın tamamı ile tazmin edilmesi gerekeceği ilkesini ihlâl etmeden verilen zarar tazminatını düşüremeyeceklerini düşündü. $\mathrm{Bu}$ karar, Temyiz Mahkemesinin bu oluşumu tarafindan en azından bir ilkenin teyidi olarak oybirliğiyle yorumlandı. Mağdurun durumu iyileşmeye yönelik olan bir ameliyat geçirmeyi reddetmesi, asla hatalı olamazdı. Soinuçta böyle bir red sorumlu tarafından borçlu olunan tazminatın tutarını azaltacak mahiyette değildi. Yine Ceza Dairesi tarafından karar verilen ikinci bir davada Neuchatel'de ağır vasıta şoförü olan mağdur bir trafik kazası sonucu Pontarlier Guraba Hastanesinde vefat etti. Tedbirsiz otomobil sürücüsü kovuşturmaya tabi tutuldu ve taksirle adam öldürme nedeniyle mahkum edildi. Hastanede kaldığı sırada, Yehova şahidi olan mağdur inançları nedeniyle durumuna uygun bazı tedavilere maruz kalmayı reddetti. Hastanenin tüm personeli yine de, yaralıya ve çevresindekilere eğer kabul etmezse öleceğinin kesin olduğunu haber vererek, yoğun bir kan nakli yapmak için 1srar ettiler. Baş Cerrah hastanın keza karısı ve çevresinin eğer hasta durumu için gerekli kan nakillerini reddetmemiş olsa idi, hayatta kalma şanslarının öenmli ölçüde artmış olacağını görecek olduklarını beyan etti. Dul kadın müdahil taraf oldu, büyük zarar- ziyan tazminatları istedi. Besancon Asliye Hukuk Mahkemesi, sanığı tek sorumlu ilân ederken, mağdurun bir hayatta kalma şansından mahrum etme olarak nitelenen tutum olan hatalı davranışını göz önüne alarak tazminatları azalttı, ancak hesaplarında göz önünde tuttuğu indirim yüzdesini zikretmedi. Besancon İstinaf Mahkemesi, bu muhakemeye uymadı ve kazanın mali sonuçlarının tümünü sorumlunun yükümüne bıraktı. Mahkumun itirazı üzerine Temyiz Mahkemesinin Ceza Dairesi, istinaf mahkemesi yagıçlarının mağdurun durumunun zorunlu kıldığı tedavileri bile bile kabul etmeyerek kendisini bir iyileşme veya hayatta kalma şansından kendi kusuru ile mi mahrum etmiş olduğunu araştırmayı ihmal ettiklerini söyleyerek İstinaf Mahkemesinin kararını bozdu. Temyiz Mahkemesine göre, mağdurun bu kusuru, bu reddetme zararının gerçekleşmesine yardım ettiği zaman maruz kalınan zararın tazmini için gözönüne alınmalı idi. Böylece Ceza Dairesi, sorumluluğun üçte birini mağdurun yükümlülüğünde biraktı ${ }^{186}$.

\footnotetext{
${ }^{186}$ Müller, s. 369-370, N. 546.
} 


\section{Değerlendirme}

Hastanın görünüşe göre, durumunu iyileştirmiş olacak bir tedaviyi reddederek bir kusuru olup olmadığı sorusu, nazik bir sorudur. MÜLLER'e göre, aslında bir şansın kaybolmuş olması yeterli değildir, fakat onu yakalamayı ihmal eden kișiye de serzeniște bulunabilmek gerekir. Başka bir deyişle, bu şansın kaybolmasının birlikte kusur oluşturması gerekir. İtiraz her kişinin kendi vücudunda istediği gibi tasarruf etme hakkını kapsayan kişisel özgürlükten ileri gelmektedir (Federal Anayasa md. 10 ) . Buna bir de Yehova şahidi tarafından bir kan naklinin reddedilmesi olayında anayasal vicdan ve inanç özgürlüğü eklenmektedir (Federal Anayasa md.15). Federal Mahkemeye göre, kişisel özgürlük kendi arzusu hilafına bir cerrahi operasyona, bir aşılanmaya ve hatta basit bir kan alımına tabi olmama hakkını ihtiva eder. Cebri şekilde gerçekleştirilen böylesi saldırılar ancak yeterli bir yasal temele dayandıkları, bir kamu yararına cevap verdikleri ve orantılık ilkesine uydukları takdirde kabul edilebilir. Bu temel özgürlüklerin uygulaması yine de sinırlarını hakkın kötüye kullanılmasının yasaklanmasında bulur (İsviçre Medeni Kanunu md.2). Mağdura bundan başka bir zararı azaltma düşmektedir ("Schadenminderungsobliegenheit") . Böylece mağdurun zararın ağırlaşmasında ya da azalmamasından ibaret olan birlikte kusuru İsviçre Borçlar Kanunu'nun 44 / I maddesine göre zararziyan tazminatının azaltılması sonucuna götürebilir. Şu halde, zikredilen anayasal hakların kullanılması mağdurun birlikte kusurunu oluşturabilir. Reddedilen tedavi amaçlı müdahale zararsız olduğu zaman kötüye kullanma özellikle belirgindir; (ilke olarak) bir kan nakli veya belli sayıdaki olağan ve özellikle riskten yoksun müdahaleler böyledir. Böyle olduğu andan itibaren, mahkemelerin tazminatın tespiti sırasında mağdurun nihai zararının gerçekleşmesinde oynadığı rolü hesaba katmaları gerekir. Eğer, söz konusu tıbbi eylem ne tehlikeye ne de ciddi acıya yol açabilecek bir şey olmadığ 1 zaman mağdurun durumunu iyileştirecek mahiyette bir tedaviye ya da bir cerrahi operasyona maruz kalmayı reddetmesinin kusurlu bir özellik arzedebildiği düşüncesinden yola çıkılırsa tazminatın tespit edilmesi sırasında hiçbirşey, mağdurun bizzat kendisini bir iyileşme ya da hayatta kalma şansından yoksun bırakmasının dikkate alınmasına karşı çıkmaz. Aynı çözüm İsviçre hukuku için de gereklidir ${ }^{187}$.

${ }^{187}$ Müller, s. 370 - 371, N. 547. 


\section{SONUÇ}

Almanya ve Avusturya'da doktorla hasta arasında yapılan sözleşmenin hukuki niteliği, hizmet sözleşmesi olarak kabul edilirken ${ }^{188}$, İsviçre ${ }^{189}$ ve Türk $^{190}$ hukukunda bu sözleşmenin vekâlet sözleşmesi niteliğinde olduğu kabul edilmektedir.

"İyileşme şansının kaybı" kavramı, Fransız ve Amerikan hukunda geniş bir uygulama alanı bulmuştur. Alman ve İsviçre hukuklarında uzun süre fazlaca kabul görmemiştir.

İsviçre'de şans kaybı konusunda yasal mevzuat ya da içtihad bulunmamaktadır. İsviçre pozitif hukuku, şans kaybının tazmin edilmesini özel surette düşünmemektedir. Bununla birlikte, UNIDROIT ilkeleri, bir şansın kaybının tazminini öngörmektedir. Şimdiye kadar hiçbir devlet mahkemesi bir şansın kaybı teorisini özellikle uygulamamıştır ${ }^{191}$.

İsviçre hukukunda tıbbi sorumluluk alanında şans kaybı bakımından büyük önem taşıyan Zürih Yüksek Mahkemesi'nin 1988 tarihli kararı üzerinde durmak gerekir.MÜLLER'e göre, Zürih Yüksek Mahkemesi’nin, tıbbi hatanın yapıldığ bir hasta için tazminatı İsviçre Borçlar Kanunu'nun 43 / I maddesi gereğince \% 40 oranında azaltan 1988 tarihli kararı, şans kaybı teorisini de özellikle zikretmemekte olup, bu tarihten önce ve sonra bu konuda benzeri mahkeme kararına rastlanmamaktadır ${ }^{192}$. Ancak bir hakem, 1988'deki bir kararla, İsviçre hukukunun, bir şansın kaybını tazmin etmeye olanak verdiğini düşünmüştür ${ }^{193}$. Kanaatimizce, bu kararda GUILLOD'nun da ifade ettiğ $i^{194}$ gibi, mahkemenin şans kaybını bir zarar teorisi olmaktan çok, bir illiyet teorisi olarak ele alması eleştirilebilir. Ayrıca, yazarın dediği gibi, Yüksek Mahkemenin bu kararından şansların zayıf gözükmesi, diğer bir ifadeyle \% 50 'den az olması halinde, şans kaybı teorisinin uygulanmasını reddeder gibi göründüğü izlenimini çıkarmak da mümkündür. Olayda, ölenin çocukları ve eşinin destekten yoksun kalma ve manevi tazminat taleplerinin kabulü, kanaatimizce isabetli olmuştur.

Ölenin yakınları, Avusturya (ABGB m.1327), Alman (BGB § 844 f.2), İsviçre (OR 45 / 3), Türk hukuklarında (BK m.45 / II) destekten yoksun kalma tazminatı talebinde bulunabilirler ve mirasçı oldukları sürece, ölenin

\footnotetext{
${ }^{188}$ Giesen, D. : Arzthaftungsrecht (1995), Rn. 7 ve yukarıda, s. 9, dn. 43'de yapılan diğer yollamalar.

${ }^{189}$ Honsell, H. : Handbuch des Arztrechts (1994), s. 22- 23 ve yukarıda, s. 9, dn. 44'de yapılan diğer yollamalar.

${ }^{190}$ Şenocak, s. 18 ve yukarıda, s. 24, dn. 132'de yapılan diğer yollamalar.

${ }^{191}$ Müller, s. 181-182, N. 249.

${ }^{192}$ Müller, s. 182, N. 249.

${ }_{193}$ Müller, s. 182, N. 249.

${ }^{194}$ Bkz. yukarıda, s. 22-23.
} 
sağlığında doğan maddi tazminat talepleri kendilerine intikal eder. Ölenin manevi tazminat talepleri de mirasçılara geçer. Ölüm nedeniyle ölenin yakınlarının kendilerinin manevi tazminat talebinde bulunması, İsviçre (OR 47) ve Türk hukukunda (BK m. 47) mümkündür ${ }^{195}$.

Doktor kusurlu bir şekilde bir tedavi hatası yaparsa, hasta ve ölümünden sonra onun yakınları doktor hakkında tazminat davası açabilirler. Bunun için burada belirtilen sorumluluğu doğuran nedenlerin olması şarttır. Diğer bir deyiş̧le, doktorun hatasıyla varlığı iddia edilen zarar arasında bir nedensellik bağı olmalıdır ${ }^{196}$.

Tıbbi sorumluluk alanında, incelenen yabancı sistemlerin çoğu gibi, İsviçre hukukunda da, kaybolan hayatta kalma veya iyileşme şanslarının tazmin edilmesinden yararlanılabilir. Bir şansın kaybının kabul edilmesi her halükârda sözleşmesel ve haksız fiille ilgili sorumluluk için ve kamunun sorumluluğu için haklılık arzeder ${ }^{197}$.

Özel surette tartış1lan birkaç uygulama üzerinde de durmak gerekir.

Eğer İsviçre hukuku anne ve babalara "Wrongful birth" için çocuklara ise "Wrongful life" için bir dava hakkı tanımaya karar verecek ise, anne ve babalar için bir çocuk sahibi olmama "şansı" nın kaybı, çocuklar için doğmama "şansı"nın kaybı başka bir şeye hacet olmaksızın tazminata hak kazandırabilir. Ancak, bir uzun ömür veya hayatta kalma şansının kaybını tazmin etmek haklılık göstermez. Buna karşılık, mağdur birlikte kusur ile kendi kendisini bir şanstan yoksun bıraktığı zaman hâkim, tazminatın miktarını İsviçre Borçlar Kanunu'nun 44 / I maddesine göre azaltabilir ${ }^{198}$.

Türk hukukunda Yargıtay'ın verdiği kararlarda, "yaşama şansının kaybı", "sağlıksız bir çocuğa sahip olmama şansının kaybı" ve "iyileşme şansının kaybı" tartışılmış ve bu durumlarda tazminat talebinin koşulları varsa kabul edilebileceği görüşü benimsenmiştir. Ancak, daha önce de belirttiğimiz gibi bu kararların hiçbirisinde açıkça "şans kaybı" kavramı yer almamıştır. Bu kararlardan en tipik olanı, "sağlıksız bir çocuğa sahip olmama şansının kaybı" ile ilgili olandır.

Kanaatimizce MÜLLER'in ${ }^{199}$ İsviçre hukuku açısından şans kaybı teorisinin kabul edilip uygulanmasının yerinde olduğunu savunması gibi, Türk hukukunda da bu teori, önemli bir boşluğu dolduracaktır. "Ya hep ya hiç ilkesini" esas alarak, hastanın tazminat talebinin bazı hallerde tamamen

\footnotetext{
${ }^{195}$ Kasche, s. 25; OR I (-A.K.Schnyder) Rn.4 zu Art. 47 OR. Bu konuda ayrıca bkz. Odersky, $W$. : Schmerzensgeld bei der Tötung naher Angehöriger (1989) 7-8, $19-22$.

${ }_{196}$ Kasche, s. 26. Almanya' da ayrica sorumluluğu doğuran illiyet (Haftungsbegründenden Kausalität) ve tazmin olunacak zarara ilişkin illiyet (Haftungsausfüllenden Kausalität) arasında ayırım yapılmaktadır (Bu ayırım hakkında ayrıntılı bilgi için bkz. Kötz, Rn. 159).

${ }^{197}$ Müller, s. 372, N. 550.

${ }^{198}$ Müller, s. 372, N. 551.

${ }^{199}$ Bkz. Müller, s.393, N. 598.
} 
reddedilmesi hakkaniyete uygun olmamaktadır. $\mathrm{Bu}$ nedenle, iyileşme şansının kaybından doğan zararın tazminini kapsayan davalarda doktorun teşhiste veya tedavide kusuru olmasa idi, hastanın iyileşme şansının yüzde kaç olacağ 1 hesaplanarak çok düşük bir olasılık (örneğin \% 30'un atında) olmadığı sürece, şans kaybı teorisinin esas alınarak hastanın zararının tazmin edilmesi, kanaatimizce Türk hukukunda da kabul edilmelidir. Ancak, konu Türk hukuku açısından oldukça yeni olup, bu teorinin Türk hukuk doktrini ve bundan sonraki Yargitay kararlarında ne derecede kabul göreceğini zaman gösterecektir. 